


May 14,1894

Zeft Mimeafrohis of 7:40 o.m the

C. St.P. . Omoha R.R.

May 15 Daylight of Siony City

Writed thain \& Columbus via horfolk t had to wit again of Columbres irom 12:30 to 6:15 for train, west on 21.p.

crops grod, lots of rain, raimed all day. Cold' chilly

Saw ove Lepus canflestris T sour Cyromp. Way 16 Doylight at Sidney, Wb., breaffart Graer good all along. Stock looks well Not wany farms

Saw the titiot Spermophilus elogans 2 miles rot of Chuyenase. Saw ove autelopes just weot of Laramie.

sark ot Green River City. stopped of fossil of 10:30\% wert of bed in a little log cabin.

May 17. At daybight I foud 2 inches avow on the ground th the air es full 4 avous I could rot ere aerass the wally! Wout sut o trampid till 10 A.M. o found lots of Sperwaphilus eley ans 8 . Sous * a Sage hes. No Chifommbes. So antwy $*$ alipkery $I$ could rat get no to the foosil strata 
Hams fark

Took the 10:23 rain rack to fraus 7ork which is 300 fut higher than fosaif $x$ is clase to the divide between tams fork Rives 7 Wwin Creeks. Hunbed till nearly might but could not find a Taunas. Shof lots of 5 . aswatus but vo S.elegans. Stota Lepus anfestris on sour ottess.

the svow hift before now rut it is cald $x$ windy. Almalst ro flowess or quen plants. Thelintah Wts anc in fuet view sontts hidge $r$ are ul snowed undes. A browy hange ebous to the waith.

Topk the west bound thain of 10, T.VI. A cleas night and a young woon enabled me to waten the eostutry, and see thot we followed doun an ofeen valley it

May 18

Wrke np at daykight near Ameriean Fulls, dolato. The might was eold and ies eovened littl foods in the moning. Low whith and yellow flowers faish flowit th Inoke Plains in pllaces. Grass is well up. Saqe leaves are coming ont freoll and green. Sarcotatus is inglowes. Grayia is ullof ands. As we descend ot the suabs Kiver vally of Glums Fisry the flowers beane numerous and vequtation is far in advanee that on the highes lavg covered plaino. Wi have the river valley again avel 
Huntington

Crass ware sagebrush plains. At Mountain Howe there are some irrigated patches, tut the country tools divolat. At Payette there are mare farms and owe large arobards of your g fruit thus. Of Ontario + Wisen the Snakes i alley is wide and hurl. Big ditches haver ben taken out and large areas of land are under irrigation. The towns seen thrifty $r$ full of life. A little below Wiser tor vale lu closes and the canon of Snake Rives begins. Wu crass o the rives at Afuntrigtos $x$ find the town wp 2 miles from and krotobly zoo fat Wights than the rives. thintington $x$ walked frock to the rives r shot

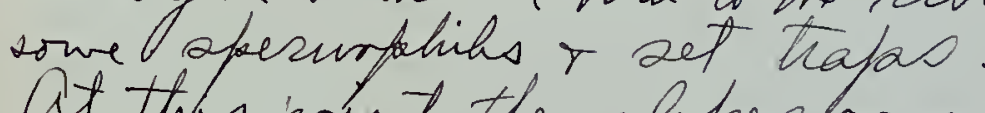
At this point the slopes cove down stuff \& tho edges of the sires. Sandy Lats and polit lie in places along the shares. A good wagon rad sums down tho rives on the wert side abut 30 niles - to Powder Pies.

The hills ace rather worth and only in places rooky. They rinse steeply from the rives to into fut or wore on each side. Ho thess on them rear here, ont they are partly covered with plants, subs, * Eagubush.

The cannon is full of flowers, mast of which 
Za Gravds

are stranges to we.

Flacer mining is carried oy in jalaes allalong th river taubs. Wrater whuls turned by the current lift the wates to wash fold from th gravel or inigats little atches of ground.

This spring has been munceally saing - crofes are growing withor muen ivingating.

Then are aubral stanes -2 botels af Huntrigton.

May 19 Canght a Thowones. Idntified a fuw plauts. Lft Aunting tor at vilo $x$ reached La ganele of SP.N.

craxeed the highed point of lave a littl east If Bakes City. Saw bey nomutaing 5 the zeosth and a ewalles ravge othe south. North Poudes is close to the lase of a ravge which semes to he the Wallowa Mts. Rain o clouds covered thi into. mast of the time so I could vot su the topas.

A light ratu has fullu all day exapt from obout /I to 3 .

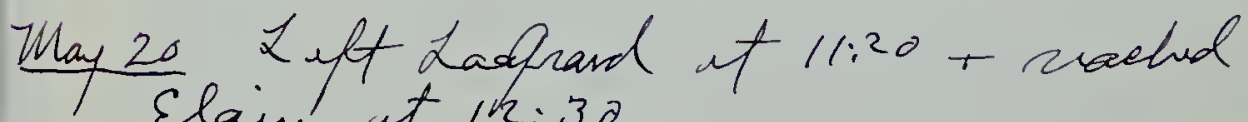
Elgin of 1h:30.

srow evers the vountain tofs on the east, west $r$ oouth of Grand Ronde Valloy but coops are geroving, fbovers an oburlant, and young spesurpticles are 
wi +3

Slain

May 21

Thy bet horse is missing. has ont tort of the pasture and gore Is bent rut di th day looking for him but without screes. Treble cave today.

7 lowers are abundant and many of the ofris are entirely new to we. are blue, others whit il.

Today was char o warm + sperightiles, The sporing has been cold $\sigma$ wet up to the present time.

May 22 Rained nearly all day. Could not do much in boron but in PM went ont + set taps + hunted. Decided क stay of the hot elf over Sunday and see if we could rot hear of the lect hoses.

May zs Foundry horae - de d stack. Went to a horse sale near the of function 1 the Wallow a + Minim rivers! but did not buy a hose. Came bock 9 miles in a hard sain + kaif storm. Bid not kill any thing. Preble caught only a studios taif but at a lot wan trapes $\nabla$ made up skins.

Mr. Stanley tills that a redfids like those of wallow a dak e ane eon m and the big marsh. 
Elgon

May 24.

7 oud a jew things in the traps but voting of great infortanes.

Sow a of evening glasbbeok filing outta grand and wotekd if yo r a long time.

Got the barber all to fisher $t$ ane ready $t$ moke camp in the warning if probe is well enough to start.

Rained in morning, then cleared up.

Whay25 Packed our outfit and moved out 2 miles S. E. Of El gin and mode a camps. Went to the traps tut caught lith. Shot a few binds. Ina de no stain. set ware trapes. Made a trap task to town and found Problem much bitter but decided nt t to lit him come to camp all toy. Guess he will not be sick after

Cooked some comas and found it fairly good. It is quiterows and solid. Seems rot to contain mush starch. has no dicich flew ar but We roasted them in the ashes. Win raw the frelbo are white, tender, butte, or milky. Wren roasted they war a host transparent, mellow triacid. Hay has ben pleasant. wast ty char. and entricly without rain. The evening is cool and clear. 
1896

Elgin.

Yay 26

Canght a Spesmoflitus columbianns o a $S$. elegans ard fisulphidrol them in a box for a that of guantity to be used.

a hay ounce in a box of a cubic foot capocity kichd them in kinisutes. Poured 100 guacts of wates coron a s. columbinus, hoh but it would fill only to abrit 8 inshes of the top.

Canght a weasel, a Zopus, a Peromicons, an Eyotonmp, a Lamias. Rest traps. Found Preble warae 7 got a doctor forbim. a fleasont day with only a sprintele $\hat{u}$ cloud of duet cave oorth mountains with a weat wind.

IMay 27

Bisuffhides spernof niles, killog Arotongs * birds. Went to todor o pound Proble triter. a bers, warm day.

Whay 28 Grotter spluoted day - Cbar r warm. Whade of sowe sferimenos t worked wart the

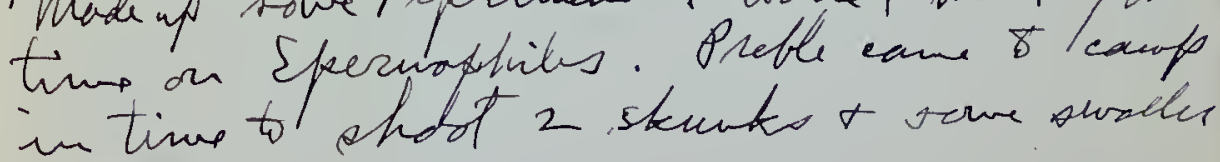
game. 
Sin - La grands

May 29

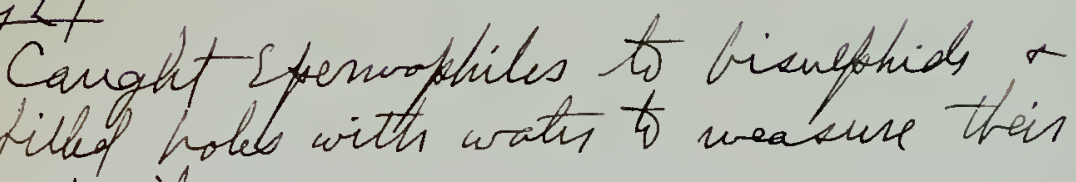
capacity.

Shat 3 Nyctacijus of cant in erring. Rained in evening. A warm day, mostly dear.

Mays 30 Broke camp at 7:32 and went south west throng h Grand Fond e Valley La Grade $F$ then ut Grand Rove R.

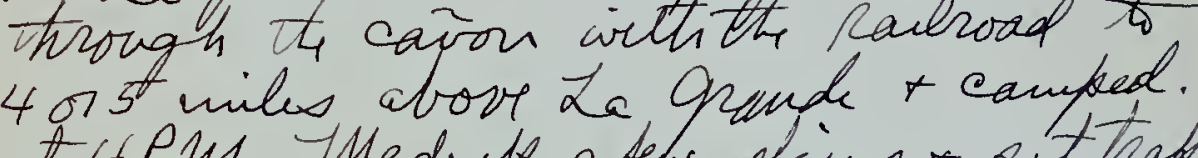
at 4 P.M. Made of a fee skins $r$ out trapes. Today is Dreoration Say + we found $\mathrm{La}$ grand all on the struts s stores all closed. Toad fairly give most of the way. The curial part of grand horde valley is sandy t Rolling: Good sail a good farms. All cultivate f or pastured. Perry is a a will town t moot of the tubs along the cion hos been cut + seen down the fives.

A clear, warm day, A cold wind down canyon in saving. 
Hilgand

May J1.

Followed ut the Grand Horde Riven past Ailgard, then crossed of the worth ide r lift the riven r followed nf a cease t Thump a lory ridge to a mile sa bal f the summit and congeal guat ats noon. shot a jew things along the rouble. Sow a Coyote al near camp pound sour preach beer sign. St trapes and wo tote some. snow banks hic on youth ab pes so fut below our eave. The enow has gone off a lately wove ch much of th y round that very fur plants hove started! On ore side the crest Vaceunium mierophy blum are in flower is on the other sids th leaf

at camp th zone is purely boreal. Pins nuvryara + Pica are abundant hold the ground on north slopes while Pins ovdrosa - Lari veridinlatis oceofy the tees of ridges or s. slopes. Came of out 12 miles! all the way up hill but with easy grade 7 fairly good roads.

Tune 1 Rained in the night and pest If forenoon. Staid in camp $x$ wot reports till room. Heated beer $x$ other thing in PM but did vat get mon Caught a Sorry $*$ save Euotump. Found a lot of Torus. Fard Calypsos boredis for the fir tim . 
Macham

Vume 2

At camp the larareter nad $4175^{-}$at 7:30 A.M. On th highest pant of th summit 3 mibs berford camp it read 4675, and of Meachem 3900. Snow still lies in dup drifets on noth slopes near the summit. The pass is purely boul though tramsitions oficies nach neasly to if on oorth obper. Pinus mus ly ava $\nabla$ Picea o Abies gravdis ase characteristre. tuis. Sove Lasix, Pandotouga r Lims porderara wach the top on ridges. The railsoad press xeens to is a title lowen than th wagon road. canpeed on th edge of the timbes platean over boteing Pendlitan s vally and of but 1 ro pert lower thaw Meadran. Cave about 18 mils.

Sit trops o wad ipsakins.

Tum 3 Canght 2 sorx. A cold worning. started pon Pevoliton, jollowed tof of ridgp about 3 miles th the descended about 1400 fut to th valluy and uachal pendbtor at II A.2n. Struck pure Vransiton zone a littl belor tols I platean and at Pendliton ther is a dicided soraran elurent in bottom of valley' On 2ndian reservation all thelwy. Zuft the timber on top of plotean.

the slopes are eobered with good grass 
Pendletor

and lots of indian hasees range over them, The vally is fine fasm land. Cropsoar good. Rye ils headed ont, wheat is r fuxt lingh in sowe fields. Wrat filds of whet ar full of weeds-espreially alfileries o littaspecmum (?).

Spermophilis bellingi $T$ columbiams wers common on top of platean. To operurobhils a toles were seen on slob. S. Tonneerdi is common in bottom of callyonly.

Got mait $T$ quat is anfoed mear torn $\sigma$ set trapes? moh op obinst wrat repart in evining.

Fheroon cold, ofternoon wasm ot clean.

7 som the edquf the plateen we saw 3 snowy peoks farts thy wed's noith. A wood hauler tote wis they were int. hood. Wht. Adams, \& the rotters ove Uht. Ravies.

Jane 4 Rained about bolf the day. Caught rothing. Risuphided o dugout spirnophibs o counted
thiis holes on an acre?

Jane 5 Raived all right $x$ past of doy. Cleared up oo I caucht or photographed t bisulphiled speewophiss. Took thain for Wivora bash! vin walla walla att- $2 \mathrm{am}$. of fumel. 
Snake Riven

Junes

Wokesp at daybight at Wallawalla, had ruabfast of Itachuor and stofened of Ti3o of Riparia when the R.R. erassesth Svabe River! Hunteof spernoftibs + shot 85.trinserdi but found ho other speciss.

Oof rovme plauts: Whot an riports.

A cold wight o wassing of cod, windy

tay.

Tuns 7. Started of 7:25 r stopped of Wirara of 8.47 7 ound onby Stounsurdi still. Bisulphided alot in bolis $r$ wote uparts.

Wivova is wel of on toff of prairie.

cliffs of lava erop out alor the creek.

Th lieg hills are wwoothe and seem to be gyod farming lavd. About half the lald is pastured 5 the rest in qrain.

Inve 8 Worday, Wat to wy lisulphice Buso hohs a fornd that overkalf of the sperwaphibs had cowe out.

took thain of $8.45 \mathrm{Am}$ pr colfox.

Saw only S. Tonsurdi till uear Dianord $\checkmark$ there saw both tounserdix columbeains bat only columbiauns the ret of way over to 'Crest o at Colfos. Ruched Colpex at bobut $9: 30$ + hinted all of a.m. Wrote on ruparts in P.M. $x$ stocted food at 7 P Mr jor Aeppos. 
Willows

r.ust - Sme 9 arrivel ot Willows funation ct 2:30 QMU $\nabla$-got a fur bouss slup byou heabent. Found mipey near the Colwubia River and in a soion of Sagebrush. Sand, ard lova socks to Roging wivd.

The vives is very high ard is an innerse strani.

Fond lotoc/ S. tounsendi and saur tracks r bobs Derodipus * probobly Perorgrotius a enychowys. Sowe of the bives + wast of ty plauts are foraran 8 I convises the valby alwart pure sovaran. savelblew all bay.

Vime 10 dugout t shot a Perodipur t a Pirograttus. Canght a Thowns, $\rightarrow$ olot a turth t ret a fin trapes near the poth o the difo. Oft oom lizaras r a crotalis.

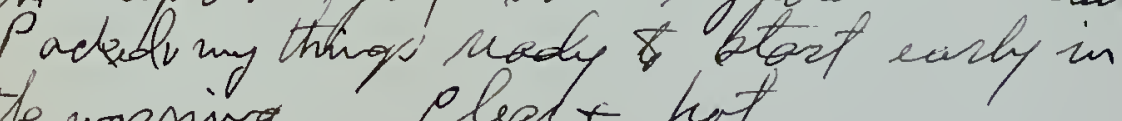
the warning. Cleal tr hot.

July II, Got up at 2 am or found ny tropes with a Perodifens in ar. onfelongs in arrtes. stabe oppered in the siot is we lift Willaw function of 2:30. Hollowed of Willow B. Hipjener tor 40 miles wp a eteady qrasle. The vally is ravowrdeny not forwed alorg the lowen half. Then are geod favms alorg the fotom whore to xefopered. Got wail. made afiers. Found S. beleingir S. tomendi. 
Hepper

June 12

Staid at camp $r$ wot on reports and tired 8 find a camp wan. chan $t$ hot.

Inve13 Moved camp to a since above tour $\sigma$ got supplies $x$ did sower writing. a dear hot day.

Jurel Sunday. bid nothing but wite shunt for wan.
Hot o clear.

Imu15. Started of 9 aM + climbed steadily up grade for about 4 niles and probably so jut altitude. Barometer would rot work. crossed a plat topped ridge and wont down av other quell of Ray Creek, ob out on a hovel with teppeves. At lunch hoer then followed up aistiver gulch for several miles $r$ cane ont again on to f fo the plateau level. Followed werasb for 8010 mils and again started down through Buttermilk Canyon to Rock Creek and Camped ot 5 P.M. Came about 27 mils. Found forms gramifield all occas the elation top and in Wotton of valley, but the seeping country is rough + Lava consul and is pastured ar left for raves.

Saw lob, timbered redyed to the last oS. L ut vo vetches tres till we reached Rock Creek. there in the canyon bottom are lots of Poparlus 
Rode Crud baltamifera, willows talkers. High lava cliffs little patches hov been cleared all along for fides The creek is copied o crooked with stony bottom high values.

tum ell Tack Crete camp.

staid al f day and shat s.ebugroduries * set ware trapes r wade af s stems Found Cots of mole ridges in the creek bottoms and ceroutracks along the baubles. A char, warm day.

June 17 Tried to get an early start vat oft es getting in on lives \& topes + helping pack wagon ald rot yet under way till

7 allowed up a side carman about 4 miles $\alpha$ out on top of the plater 14 or put above camp Had a fine view of WH. Hood \& WAT. Adams and a ware distant view of St. Helen. Found mostly transition plan th on toff. Rote of Zewisia in full flow en on the patches of lavalsock. Found Wyethia mufhicanhis.

Descended ar other gulch to tone Poole, 1000 rut below and the climbed the hill beyond 1350 fut to th of lara plateau + then don 550 fut int Lat $\checkmark$ alley. The if a long stops t 200 f ip nigher. and then dram along coned about 800 i ut and up over another ridgy, 900 put s-Thitu down to Fossil 1150 pet blown. 
Fossil

7 allowed up a crust valley a mile -r.thelf and camped 200 fut higher than Fossil. Came 30 miles and cell up and down fig hills and over mountain ranges.

Found Sovran Jove phieies in irttons of valleys and Transition. on taps of ridges. with a fin boreal species in cold carvers on th s highest. From Love Rock \& Fossil we were with oeattred Pines perchrava $\nabla$ Psendotatge mech of th tim. Juniper is common.

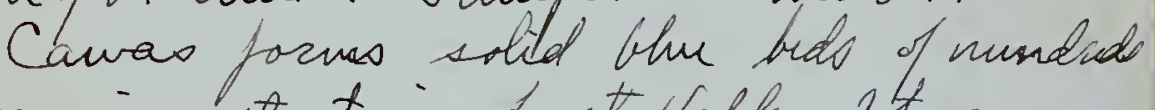
of ores in extent in Lost Valley. 24 prows on wet valley bottom and the flows stalks stow is thick as wheat. The fields of it hoorben fret $x$ in ore we saw a lot $y$ hogs. Some sow milt in Last valley.

could an Cordon about 18 riles 8 tho N.W. The whole country is craved with lava but near Rome Rocks Tonsil layers of clay $r$ stratified rock of fear below th lava. There are said to be sow frail wood pow near Fossil o bores in or gulch west st then. Spermophiles belling che canon all the way, a for. Tenias buleorutis seen, $\nabla$ clos S. chryoodirins: Law ore Pins quine in Lost valley. 
Time 18 7 un canfs we followed wp the creet a mile of two s then terned wit and clived the ridge - and strude form ont Prin Cruls $r$ followed it 5 fohn Dang kiven and down the sives a mile to tho forny $r$ cacaped. theroid at camp reod 2950, on thidy3750, of Johndoy R. 1500 .

Folbard croded, sovgh qulch with nany high cliffs avol side caryons down Pin Crecks. 7 if Bids of Yellow elay 5 yumbo 5 gafkum avel strotifief rock ofperan in many plexes look libe geod grourt for fos ails.

struet sovaran zonte at obout 3000 ut Caveroid reading) in Th gulch $\sigma$ pure Sovoran in vives valley.

- Aigh convthy all soeky o rovgh, grood prases

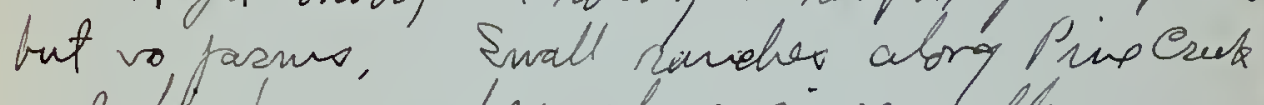
and bly hay nawehes aborg sives valley. Rye is saised for hay ot is the wain crofe. Good arobards of apple, cherry t, beach tues Parsed the Rold office of 7 ranciville $x$ Clarne. Crown Rock P.O. waed to of thefirsy but if was ataidrsed $r$

the P.o. a) Clasne istoflishef near Utr wovith f Pine cruck and nawed for old wan Clarne of the irsy.

This old fillow is a cbacacter. Sitted here in $44 \mathrm{~T}$ fit injums + raised cattle $r$ bocess. $T$ several boys. Lo very igrarant othelf wours mush that would be of value 5 othess. Har a galliction of "corrasities", indian 
rulies $q$ "putrified" specivers. Explains the lava rock formation as cauned by a great "voleani corruption. Says the boulders aloug the sires do not friong heas. Thay bars coner from soure faciign conutry, lí ean vot get washingtor lreated-cournof sepecota if from washingtor state.

set trapes for Pirograthus fot found is signs of athes wannals. S.beldingi coves down to rear the south of Pine br. but we found rove in the vally.

John Daykiven is mot grith solarge, w tho Bigtione. It is rapid, muddy, $\sigma$ crooted The campon is alonghere ofeen 8 valluglites with vorflowed botous in plaber. Rava clifes or tutts rise z vo ilet. Rocky o atomy ridges slope doun to the valley. The sift is dry + Haked $v$ the plants are desent life. a few striksd funipess grow alorg socky slopes. Wilbus yress along the siver baukes The fur trus are evidintly introlued as wast f then are Lonforely koples. Sagebrush + Rigilovias an the conopicions vally shrubs. The flood lowd are all in rye. 
John Day Rives

Jume 19

Canght only Perognothers \& Proble gof a Hus nusenlass. Crossed the firry $x$ camped ot spining $\frac{1}{4}$ of a mill bdek fitor sives on beat sidi? Waderfs skins set trafis $\checkmark$ oldt bats $\sigma$ piebed up poosil arord. U very hot day.

Jume 20 Canght a Peromiseers 9 Probh eanght a neotomina.

startiel for Antilopos of 8.30 and climbed steadily abret 8 minles to wasthe sumnit of ridep and camped by oove spaings. Aneried read / 1200 fut at camifo by fohn Day Riven and 34 or at Coday eamp. climbed to top of talluat peat when averoed * Ramies t Hod t a dozen peaks dorg the ringe farther oonth. Could en aerass to valley of to Dos Chuts R. and far ap the form Day R.

Cought a S. wolles traw wore. St trapos or chilotios T Thowsug or preble sut arme Aratorny tropo.

Found a sanshy patten in the gulde about 5ovfut arove the wirs x foto of Perolgow troks o hols in it - Fnut Prodepero trgoto ip \$ 1200 pt dove sires - Juat whure the firot sperwoptiil trates whe seen. Tot ain wasing of wives but ad on ridge $r$ eold in weining 
Antelope

June 21

Canght 2 waouls - 2 Thownup - a Peromixay 4 Chilotus a Sinollis, becidh the hot caught SM. drove dom to abtepp. Allin tod not a vived, got rowart, but of com supplies ar a aw the city.

compe divide is 200 fut highes thas oun cinfes. 2t is in sovardus below ths in a elayt gunbo valley where wammals oeem to he reanes. Sow one, Sinollie vear torm, in other manoles the town consists of arme zologen houses. on yord store $x$ elome thers. 4 sotets, sered valours a clusohr P.O. 27 is in a littly farsing ralloy. In a tuelers vegion.

$J_{\text {ture } 22}$

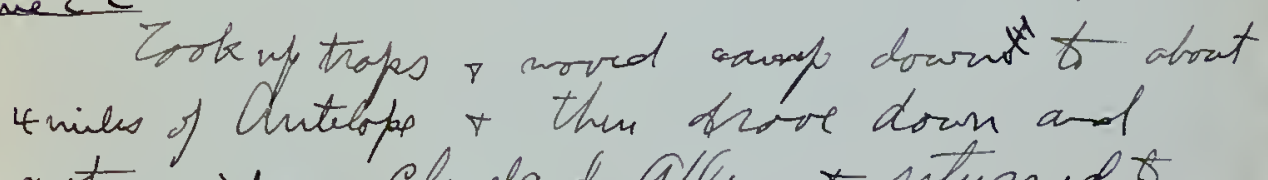
got mail + clovelavd allen + sturned camp - out traps.

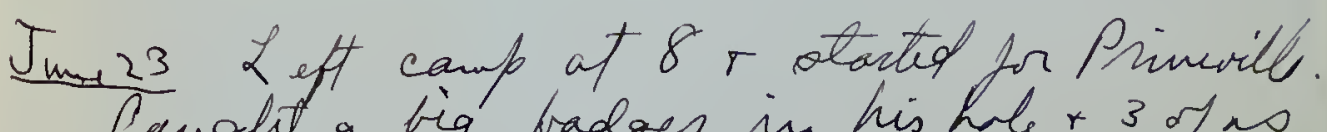
Canght a big bodger in his hale 3 of as conld not pull him ont the we got a corpe on ou foot. Passed cold Conp $r$ followed. the upper road by way of Zrowt Cruk $r$ canfeed within abritt 4 miles of tray cruk. Crotooed biy ridges $r$ rough country 
to Privevils

with good grass and few rawehes. Sorm ohuf $r$ a furlorsco - eattl.

Found S. buldingi with s.nollis.

Jum 24 started at $y$ and in ofout $\$$ miles tay creek. Folbowed up Hay crule, aver a ridge \& willow ecche, then uf a sidge to pine timber and down into Crobed Rirs valley to Hivevill. Crooked thives vally is a hroad, dry, savdy, wagifush vallsy of the Guet'Baoin typen. The ktot, dry sand is covelud with tracks and sumways of jack robbite. sfemophis,

Son fth vally is iscigates $x$ good the coads are divoty but fairly good.

A tot day. Toveled 28 miles. Camped of a paoture $\frac{1}{2}$ mile S. I Prineifly.

jure25 Mach of a fer opreinens, wot orme on ufroit It yot buaktoond

piref o vaght arfofiles.

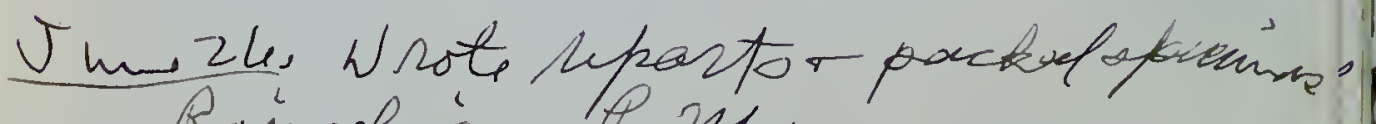
Raived in Pins. 
Qeboeo Rivn

Jume27 Luft Privevills at 10 A M on The Surns stage road and traveled tip 4 P.M. F canjeed on the rank of. Qeboeb tiven. Came obout za miles. civeroid of privwill read 2800, on ridge 3950 , at emp 3250.

7 iom Privevill cor followed up an opun wash or wide caryon with rodery. cuder covered sidbs for oom 5 , riles and came out on llovel torped. pleteran. Then we went up and doura rielges and fivally stcuok down a croobed gulch and pollowed it till. we came Ochoro kives $r$ canfued. At the highist point we were cose to Pinus porderasa but did not quit seach it. juniferons virquianus is comminu all alorg on rocky olopes. Sagebrush 7 purohia hithintata an abundant, but wast oo 5 lageat in the lows vallapo.

Both the erodeled pives vally of Priverill of th Ochoed Solly are oovocan.

Set trops.

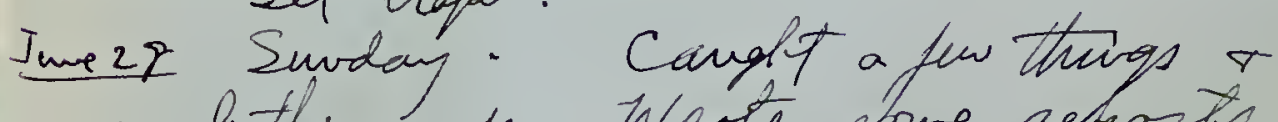
wable them up. Wrote sore reports $t$ staid arl clary around caufo. A thunderebowes pased by in P.M. and cooled the air. 
Maury Hts.

ins 29 Brobecaup ot 7.30 * Traveled up the rives about ( 4 miles and turned f up a wool road int th easter d of the Maury Uts and carped in pine tubes at a point a little below the meat of the range.

Aneroid read 33 or of cup, 3500 at a point near where are lift to nits. $r$ ircoto of campo in tho wits.

the valley is dry 7 revolt iv colby $x$ covered with raqubush cedars r Persia 5 main sovran plants

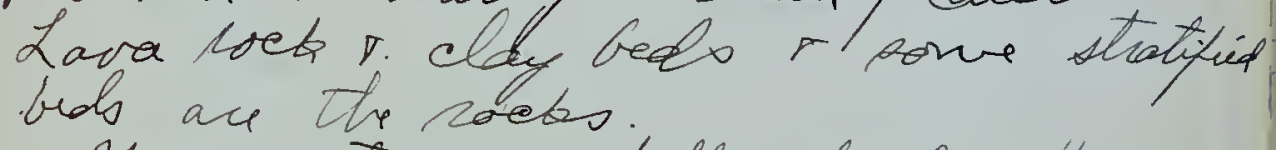

Narrow strips of bottom land along the rive are rove fields. Higher up on the sides If the valley the sagevmeh is reade gros's is better. At the edge of timber the grave is splendid. Spring are

We look across Depose Rives ot the east r see the Blu Unis. This extreme west end is appoint is.

Jumbo Caught a few goode things r Publ shot owe binds! thad y up a tot of ain $\sim$ in $P=M$. went afrit 4 miles west dong the range and out top. Sem lots of been tracks

The higher ot part of the raves rue hes A probably lo od tut. Babaltie 
maxses $f$ rock crop out aloug the crest * sichs of quldes bit wast of th Wauny uits. ase covered with good soil and grass tribes. The slopes are long $\checkmark$ guntte $\alpha$ lacily chinbed. Bilow ths trees thr woods are querolly open $\nabla$ grasay $\nabla$

Pinus pondirazar Peeydotanga ope the pinaiped thus. They as largtt clian $x$ thriply. Lavix oceidutatis t abies lasioeacs grotut on notth plopes, funipers virquianin $\checkmark$ Cireocarpus ledelins $\nabla$ phohia Nicinteta grow on rocky oouth. slopes to the top. Ceanothes velutrius is osumon from below camp $\&$ the sumify,

Ouly the noith alopes appear to to trus bareal jons. lis in Transition.

the following nammals ceaces:

Thow rup. Mirstis, Promprows, Tamias. Spermophihs alripoodius, S. Goldingi, Sciurus, Thotown, Cariacus, Bats, sorex'. 


\section{Camp Creele}

- Jily1. Lustrad of utroning down the wousutain tor wern we came uf we climb stilf higber r crossed the ranger o cauredorn the south slofe s Canpe crats. Leanned that ther wene foot foricis in the

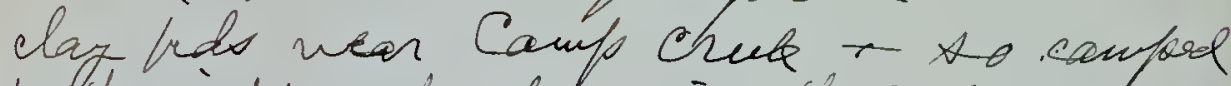

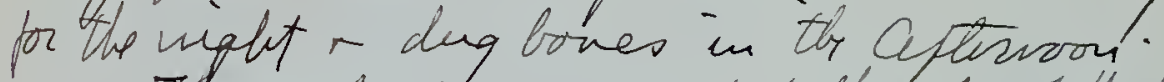
The grade is eary uf both hides I the lict The routh slo a is eovered with trubes for sweral miles down 8 tres ase many lixtle starings crectes. fracs - flowess wate the ofeen woods putty $r$ atiractios. Dact trocks wre seen in the tisile, at caup the averoid mad 4600 , ou tof of tharawe 5400 and at our canfo on co ot the taxsif beds 4250. A few Sovoran plants afopers in Camp

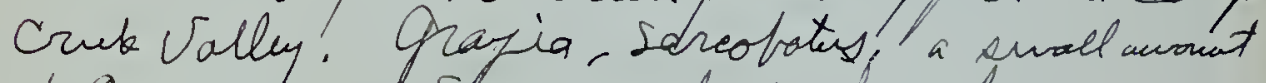
of Oryzopxis! Sagibrush predaniotes. some bid manches. not unch wates. On the weot eide of Camporect Valkey struds a irigh. plat tolpoud futt with pare sides. To thi S.E. if if ts a bres, sound topped kenoll resill byoind this another. We went afe a gulde hetween thear two $x$ at tho hal of if ufe the bank tour siegt frand a fine foosel stalitar of some mamnal. The steall in a guneral way the atill a reas twas abowt as fig ad a blas beass eidonl. is.

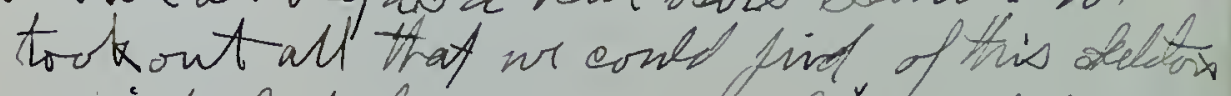

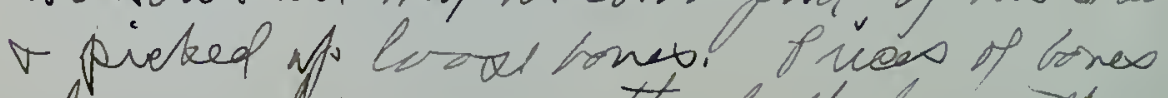

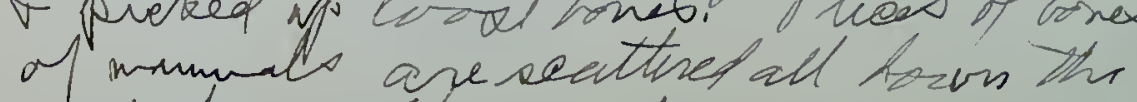
of loh. The fasib ace belled in 


\section{Camp erute}

gray $\checkmark$ the r yilbw clays, or soff rock. The sides of the butted ase perfotly bare of veritation', much eut rebred ufo, steufo and all sourd as pustly bodlainds ass ever saw. Lava sock cafes the tallest butt, + boken pieus have fallu down.

A dasle coloud ponies on searea jull of irrigulas prieus o blocks of othr sock of * parus. The forsil bedb are considurly tilted.

Iukyz Tolbued doun Canfo Cruk Vallay a fur miles $r$ then crassed own a ridgs \& the sonth $r$ into a bigdxy Gaxis a then socs avother riolge to lnwle Crukr cauped for the wight. pacsed pave ware clory bide in Camplecuk valley o

ory, sogebsush eruntry all tho way with lava cliffe all around.

$$
\text { Cave obout } 19 \text { miles }
$$

July3 Continued uf throvgh the big sagebush basin pact aboit \& wiles of marsho alkalie flat with a lacese clut corning

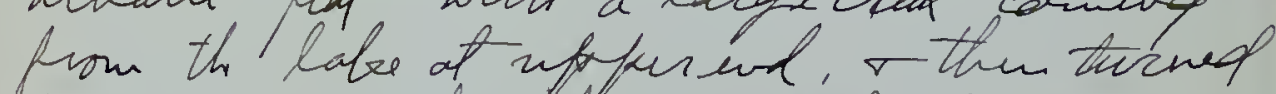
S.E. over a sliglit sises and lown $\forall$ Buek Crak. Followed aft this I rear its had t eanped at th head of ove of its

Some oovaran elewents in calley. Amphisfiga deen. Sagegrows comon. Cuveroed busted. Qbsidian flabes all oves vally r tom assow heads. 


\section{Zo Silver creck}

- July 4 Folloved uf the dry guleh \& tho S.E.

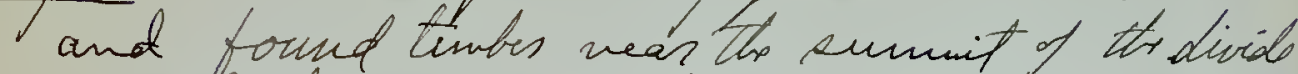
haveled through pine timber about 8 viles and carve Stan a slight grade till we rashed Camp Curry Sering on silves eruk. Foud ro wates over thrange but fin grass all the way. timbup sidges stuteh wan wect thigh buttes. peedes stand up beyord the videis. Steinints. show pleninly prouthe uffer end d silves Crecte Volluy. They are well covered with avow.

Followed down th valley about 10 miles and canped of Rilus on the alkalic plot. Fined the overoid at cony + act it at 4125 on sumint of range it read 4700, The tiurter reached down on south slope to 4100 . at Silves Cruk it nod 3750 rot camp3725. Cane obout 30 miles. Hot $\sigma$ dusty. Silpeser. Solley is a great ragebush plain with wide opass pots all alovg the atram. Princovered ridges rise b the vorth. lower ves with junifue rean to the vouth.

Tuly 5, Sundry - Stacted lonly r Toreled 20 miles * camped at roon at a foint of nooks 4 niles south of Burns wher serchol lacge, wasm ofsings coverout of the rooks $x$ Llow to the was was of Malhur late. Anained in conts the rith A daey. Sery thoty $\square$ hot. raveled tor sage bushr liva cowtry but bitte doosth warde. 
Durns

July Droor uf to Burno $\sigma$ got wait $\alpha$ subphes v wode up obin's oct traps. Hot a tuoty.

Tuly 7 Sef wore trape shuted over the tig warsh $r$ wad skius $v$ pooked oprevivens.

wathes fot toy.

Qbsidion covers the yround in swall biees that ravben chiffeed from arrousteads. We bove fortud an nubler of yood ofsidian arrowhlads. Bitween heret Silver Creety we crossed viles of comostry where of sidian Goulders were seattred vor th ourpese. Narhere sove of the washes fring tours much of it in twall picees.

July \& Brobe caup t weont of Burno 5 then cast \& garney and ther wened woth up thr Rattlesnobs Cruke of Rings Will abd thu west a mil, and caufred just ovis the divide, on thr heald tratet brup. Fom Burns to tasury throto casses grassy plot wost' of the way and is swoott land yood, but veryldusty. The jimenss warsh eflevds oouttit Malheur Labe. Crossed vo strams exapt Silvis R. at Burns. Entere pine timbes 7 milis woth of Hamey, and campel moles big fives with good grases water. Anecoid nad 3550 of Burns, 3650

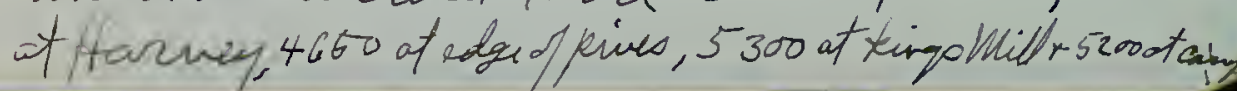


Bluevelts

Tuly y Wadeuf yestrdays steins, lunted o pripared for towo nours poek treps.

Fourd a placer mining canch just, How we r praspiet roles all over tor hills. The corwtry

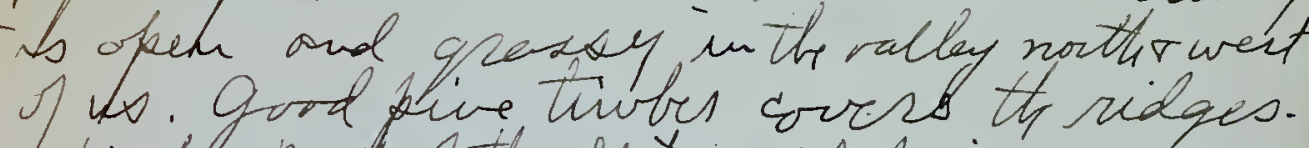
t higitr parts of the Wiks. Wotes is seaies. high up fut atcous cove out blow ns. Thy whole nigios seews to te hansition. Coville arrived in eamp ot dusk.

July 10

Wout down to Atarnay with boill * came back up anothes road farthes west. Stapped of Wh. Ofilberts ranch

July II startef for the Mts. mar strawbery

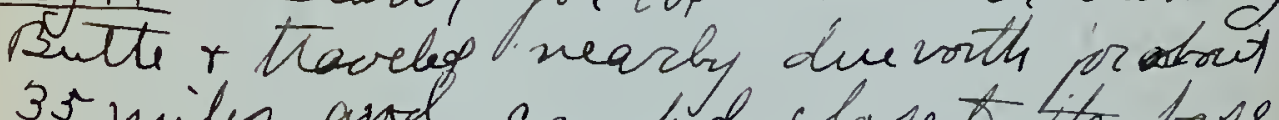
so miles and camped clase of to base of the range. passd throgh sweral laren valley with grans ranches and lots of stock but ro crops. the loweat point reacbed was 4800 camps was 4050 , oun night carpot is. sos * is awory finus nurrajara on

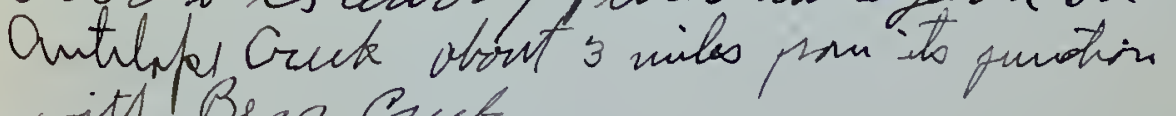
with Bear couk.

July 12 Followd dion Antelofe cruk ot

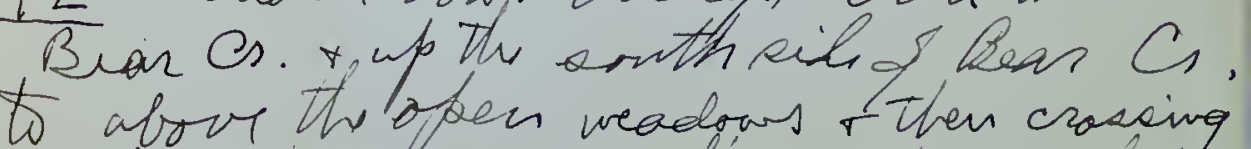

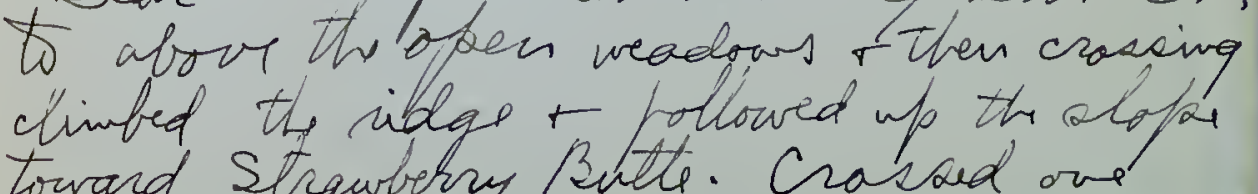
toward Strawberry Butte. Crasoud ove crube thot perand west $t$ then befat on the 
The wits

Crust of the side till w masked a point at 7000 put about 2 miles south of the percale I Strawberry Butte s camped by a creek that seems to How S. E. to the Mallow R. Had wo trails all day $r$ hid owe hand climbing fut found seen woods nat of the way. Pi nus muhryara had

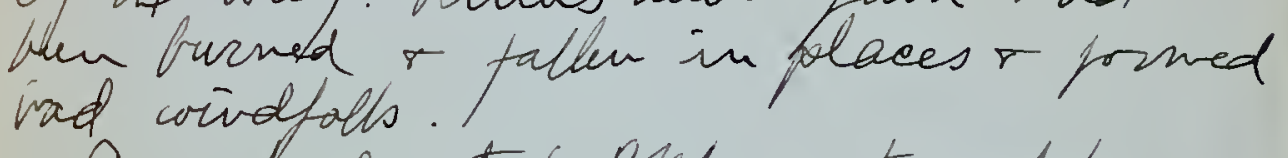

Comped at G P.M. got supper o at 40 tropes.

A coot dey with thundershower.

July 13 Went if th wits. So to of main

ridge. Could ser down in its the form Does ally and oo cs meh contr. Cosilles aneroid sid poor put on top? rave. Big arrowtonks are muerovel. Thy

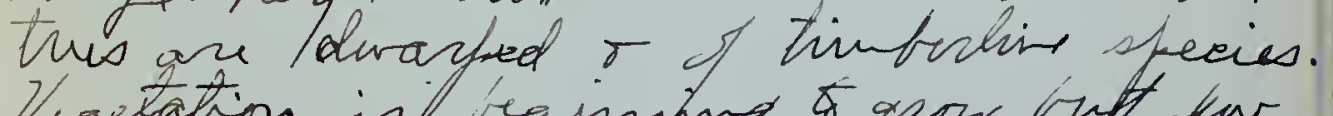
Vegetation is reining of yow out f few covers are ont. Much of the ground is are. The ascot is cocky t rough, nasty stratified cocks. Glaciers hort plowed out bour of the yolohes long age fat na st are slant botowe f om erasion.

Role slides + to sties or sou slides as e common. A fur little green labs wise sun in the gulch east If tr e But. Cavil - Olla went ot if A streabrory putter found it 9100 fat. It has a timberline tat if ency be only-grom the base codes 
Afies ontring alfieanlis grow of to wittim a fur mucled fut. Tth the as otunted dware The peak is ohahp $\sigma$ looke peryotly wase int Coville prund plants 8 the Its.

Lagoums wese reand in the geles on its sides. I Rewained on the vidae s slot Lag oung

+ S.columbianns T Tamias. Boval Jorr begins hlow ow camp, querally, af obont 6000 fut $r$ is narbed by a jull set of Stants. birds namals. of its orr. Thandition zove covers much of

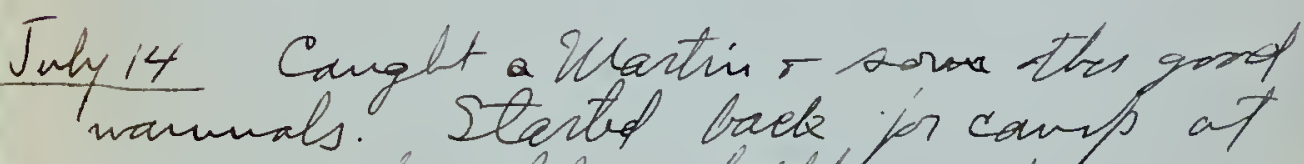
8.30 5 treveled a littl 5. of de cown the olope ill w wached Bear Os. too far to th east. Nod Bo follow down the cauly olout lay a day freou coning out of the valluy. Crostad iclas o otrucle Avtibfy crete at lowes end of rig meadour $r$ canfued ot head of the weadow of a sulfohn aforing. Sour one den, - filld a blugrnuse covills

- . Allum earde bitby a Soge gronas. Bear crute is a fins thont stream o llowes throvgh deantifht ping woods full If dees. The wrods ah wooth sfoen and grassy bereoth thetur. phuns pordiras $r$ Lasix orecidutalis are lacge $r$ hardoone ines.

$$
\text { Cane obort } 20 \text { sinles. }
$$


Bene vits.

Thly purhed trough 8 caup wher we arrived of 4 P. W. + fourd Prible with a good lof $A$ opeinimons arad up during on abrence Ibot sather ofort 1 gwt. Made ef sone of an stins t

tanney eregon

Wuly 20. Dr. Wheriam arrived by otagh. went \& hd thoroughty tired.

Jubll Finished wabing up skims in AM. $r$ after vorn stanto/ doun to Harney

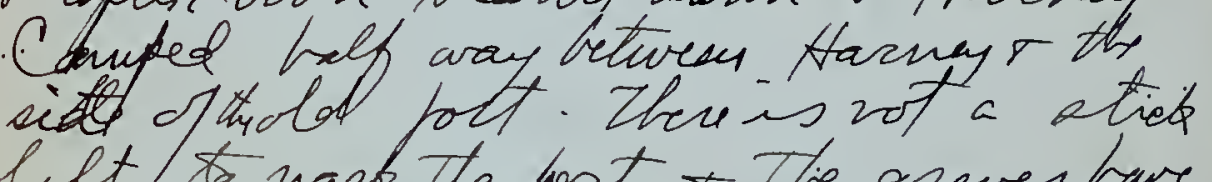
lift to nask the fort $x$ the graves bare foun dug if o the boves rewored to the hat. Cin. of San Francies. Canifid of the raveh of UM. Pain wo hastreoted ws with unusud hasfaitality t tas given us sove goof information. in regard to esopsts groud aguisists. fulyin. Stayed E. Q P Pible frow vere on pourval 5 D1. Mrrion will beef journal po our trip.

i. Barley fuly/\%. Ltaged in camp. and mote meststo meet the stage in che mommy to meer it I nesine... tut hetaie not come.

Guy 18. Pemanied w cans Baing repiated hio nient to the etage 2 stemics. July 19. Canght a ert of apecumius 

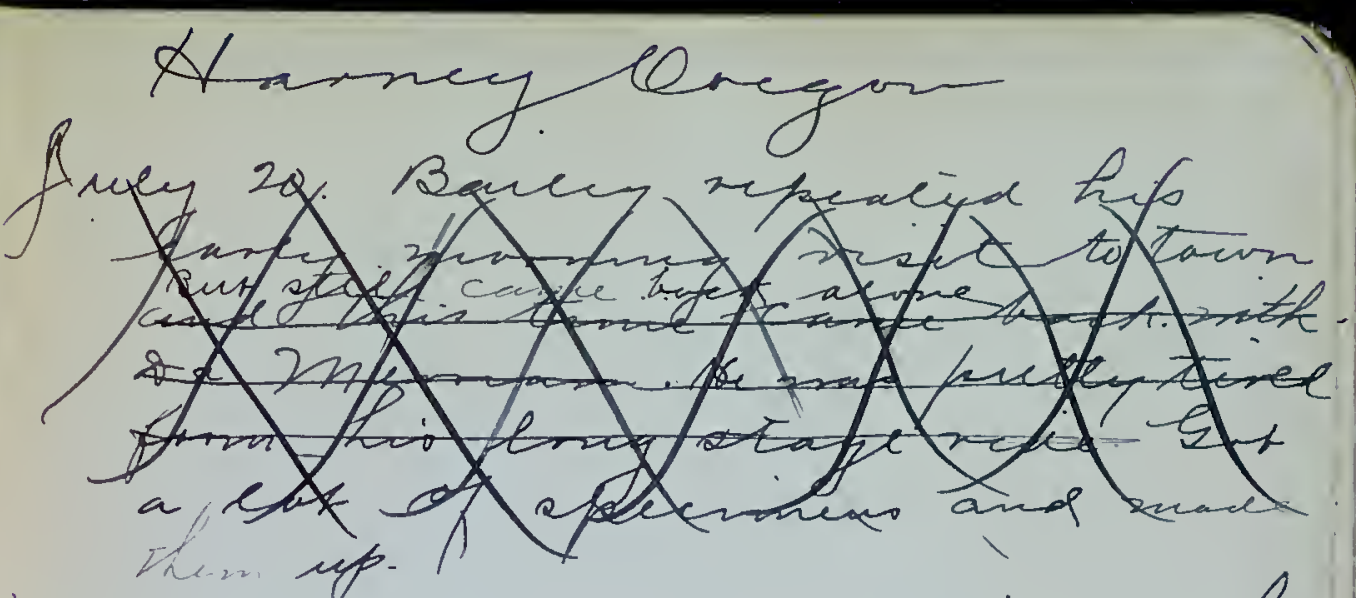

Huly 20. Dr mencein arsuid by the to comntest stage. Sivice mahing eeft ns and zrent dront to that point in gat epme specemeiv ande inte of termovif after qitting: a supply of promivins ne left thancy and tranceed torman Bums to find the Lione of cueps nfom or menum mated pos hize to feack on the tins through the Steris mts. Drancelee numel zyarly 12 and wrred ot a hrusd mhigh me supposerel to be culps. butcouck rangino one. So camped for the nught.

Wuly 2th Cearming that cueps rauch eras about 2 or ismee detant ne. left bifor gettigy Zrangast and formd thitt Le Lad gone is get wurther foit. He connuex 
xe asmed at Selveis ereets suaffast. In the meanterine Bacey had gattin anothen man aftir kneatifast we. entinued exmo Bymo where ne gat a few at on and went on thas lumeh at bur acd canpong peace at the 2 ram op hug below Buns Cntinuedon to ablout a mile from che Narrows mere me comped at a ranch as it mos late traveled abaut is mules Betrreen. a ranch abrut. 10 mule from Burn aced our jight Comp about. 20 meces cters in not a drof of ratir on the Paad

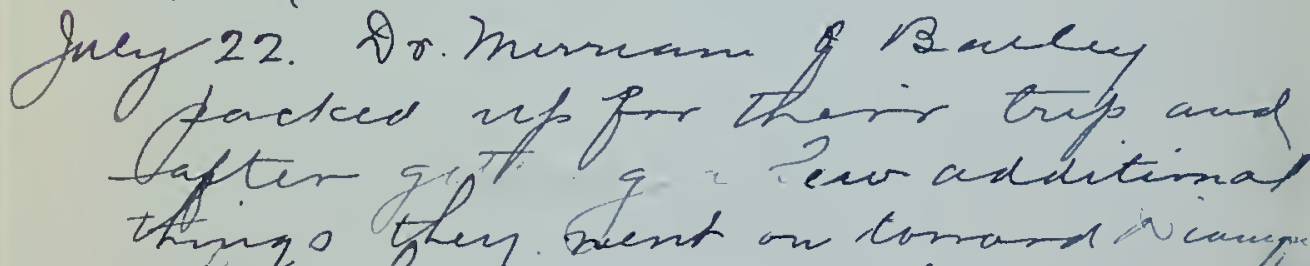
ithig thif ixpected to andie that sught tye casoped at the narrow dud set ovit emse knpos. The

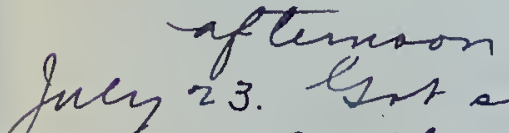

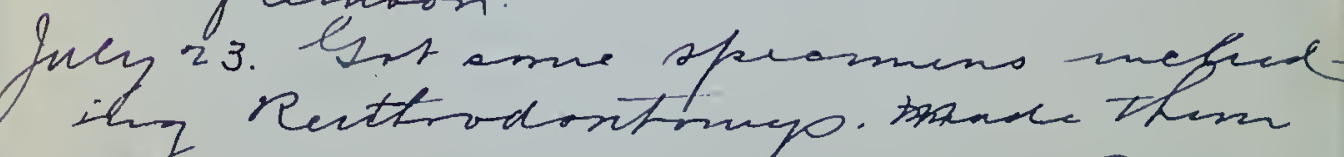
up and set moretiaps. Azade ef of rratir brids soted abrul the "harrovis" a slrugh abrut 
tya bindge. Lhere is almat

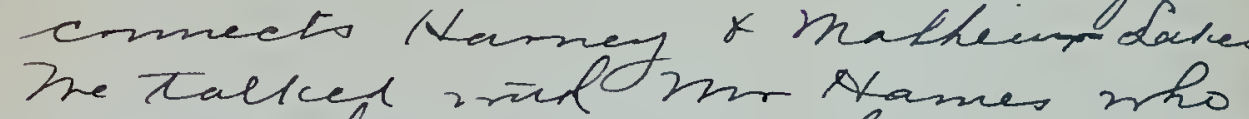
caps the strre and he gave up Sime informatipets abrat the This markes. about here mere acl mader mater and a wast of isallece bake. Harmer treatom scand wedige to 8 andere it aldere

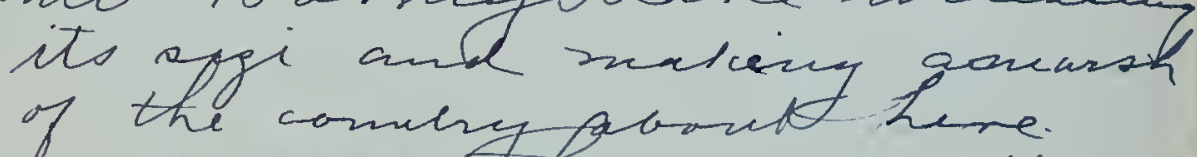
and faferchy greatic deregenz the suting nathern w it ax at bo Lut kasmey so by for ithe for inst. The it be wbont 18 meles at finesut

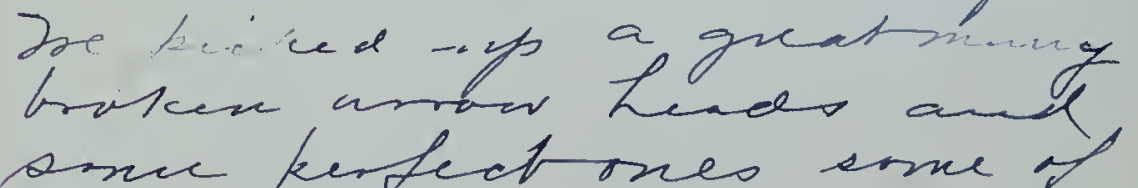
omer ferfect ones sme of july 24 isement

$\checkmark$ Remanid ni casnp. Lat nose speennems ande suede ther 
buy 25. Stayed wi our camp and gat a est nerre ofece mens. wucks ayd guece verp crmmon waret the surshes. guly2t Antwe te lecine Vh. minim lint cuught a ed to stan areother day aced thy to get some sure. Setart nerrelp ate one suace traps si the eand patches.

july2\%. Canght a lat of opermino mivading 5 prondaporaps Left camps earey and started to ivald Peles if prostile. lot off an road a lettle, anel

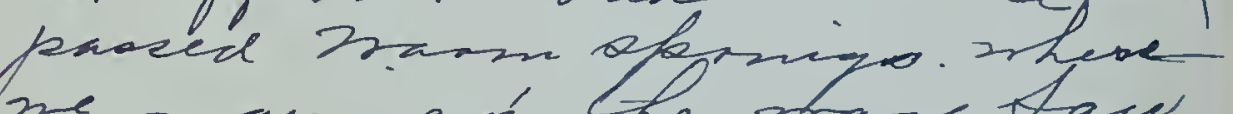
ne numeri the stray. Haw. S. nothis absut halfotray betwon ngrrows t zam op sho. Peacled Piley aldat Poucbots Lnmz trareled abant Ho meles Aneforid read tion at Pilup. a caul day with fuly 28. Ffemued, the mammaes latere the day before and

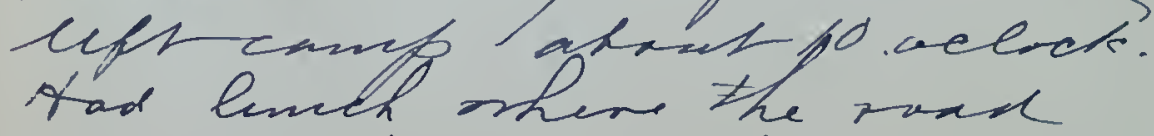
passes dilsur Prect aud reachel at 4.45 Anerolie read. 4800. 
- guey 29

Leftramp about 8 acerek and Fept on baek on the roud tamand Prnevele traveled nesvey zo meies and canjed nean. Pruct PL. Aneraid hend 3850 .

Zaly 30.

fury teph on the Rade conara Ormeriei rutil me parred Crme Q.CQ gand then trook the ruad to che left comal the ovo Chutes Ruver irarcecel abgat 3o smeie gin canper on the ude of. Che Bear Creet Bubto Aneroind read 42 ov at theplace shere ne structi che hea Bear creck. or a brawch of to nerr Crook Pro.. Cit the Redie neor Croot. th Regreizue a lagoo and at ver camp on the base of Che Reartheek Buttes troo. fily 3 .

$$
\text { Lefer canp earey. is Lin re }
$$
Lad gone about? soneis came to a crom 12rads where a sugn brour sard 18 mies to Imurele als ne needed grami ne cuncluded go to Prmerceie and firm there. not farout of are may bunky Prmercile about 2.30 and comped Aneroul reade 2800 . 


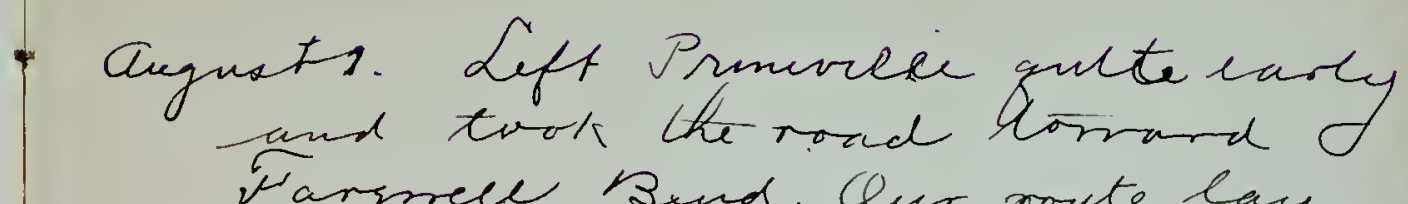
oves the decest all the rray rith no crater on the rray a custance of 30 miles. Cedas mere fornd del alorz awd ssten mithin abat 10 mucts of the send. ire passed thyough ginte extensine grvoses of

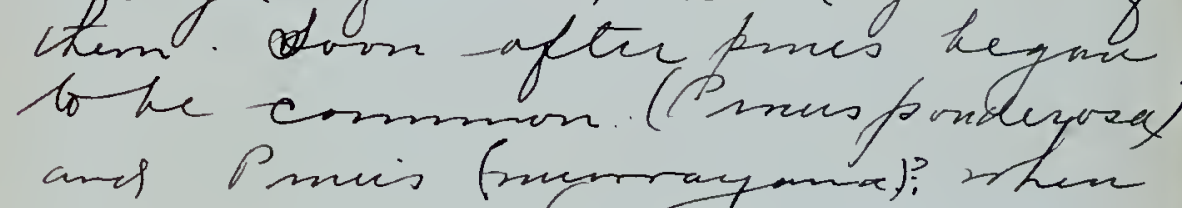

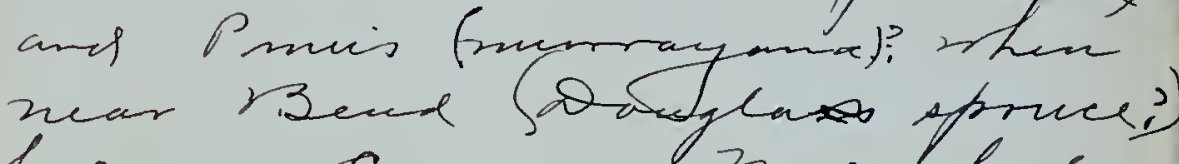
became Common. rand about 4 achert and falcorred up the suri wavat 5 mies, then me carifed on the ses Chutes Piver. Put rut a fur. L.apos and cunght a mesive fract for supper.

Aug 2. Putout menctrafas. Taw ane osferes neat pust below aur eamp. 2t cintianed large young

ang 3 .

Pemanid mi weer carros and setmme traps Lat sazue spee moves and maxe then up. and canght sime trout at 
Auguat 4

Drot up oce traps and got a fair lat of sfecemino.

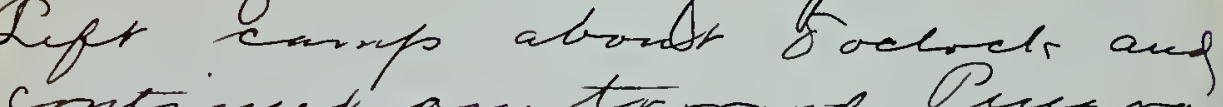
crherend an tirare Puegra ande th velvet. Peng toed recauld yench Panenia Late from thet pornt se cunper and made efp our apecomenp met a mew to reaching the. Saxe thofwelorring day Acurvidrax aug 5. Reng toed mecaued reach the Dafce ay bucklebrace sore left oner. Bade ascepting sotht re needed fir a day or tywo and startidy torrard the Kase. re parect though a ence

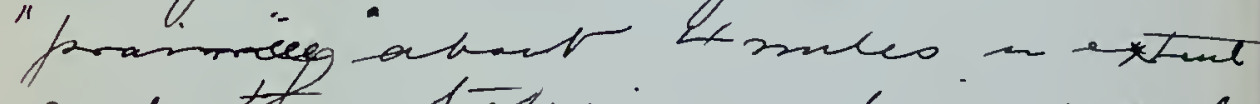
and then taicing a disin road ne uncind chl

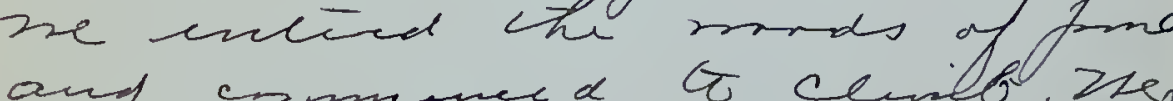
had some inosole in funling The road ot triner but gat alrng reel matil srith about 3 meies of

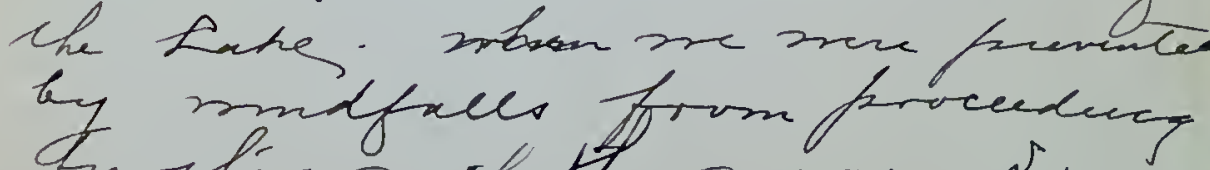
furchir met the magne. ot re parked and bagjage lon ith two tinie to putoul a few traps 
Qur ancroid registized about 6.070 at the ourlets of thi diake and the gentemian at the ranch mhare If left wirn loare sare thet ar he had fromerey wiend a basometer and had taken readnge there aftion

Anguat 6 .

peak Cemived to che top of the what above the Laree to acentar

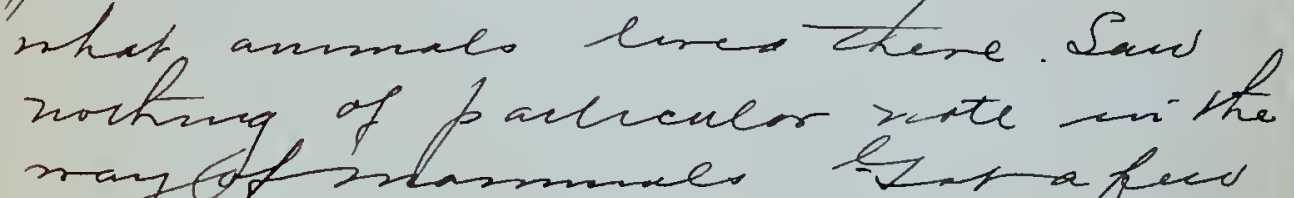

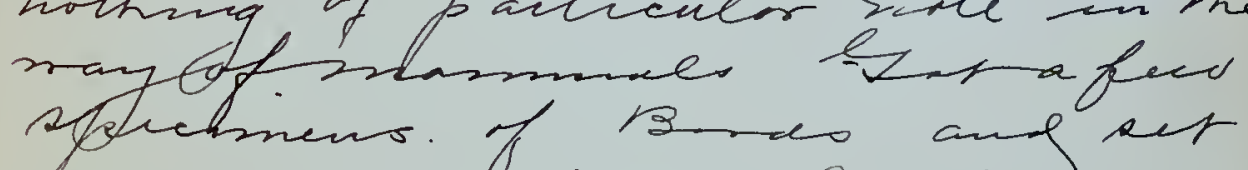

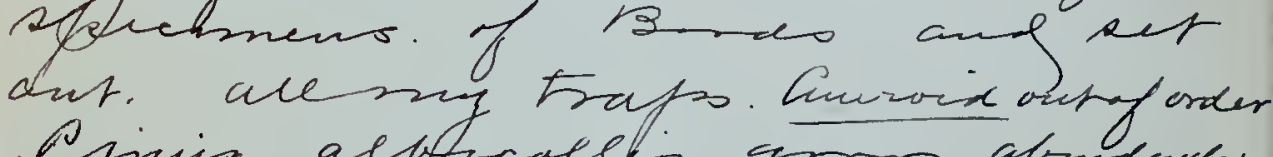
Piniz altrovellis grms abmecuady on the sment of the nits- Sauglas

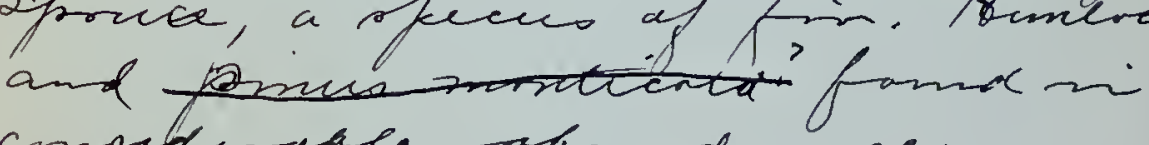
cmeaterable abrudace o.

Aug 7.

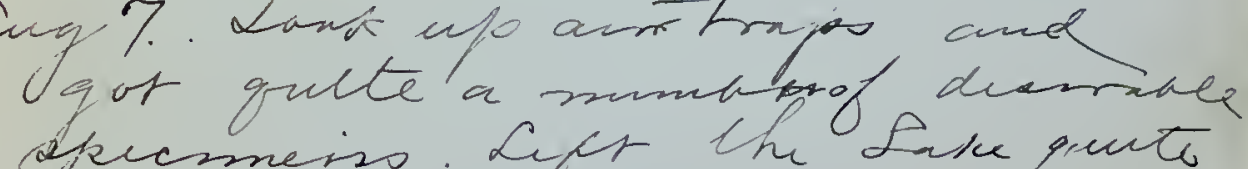
secmeiss. Sift the Sake quevt afle and reacher arre wi trime to fmoth up anfor stevemens.

inglf. Sift arto enups gi the mang cun Franceled enctringh the

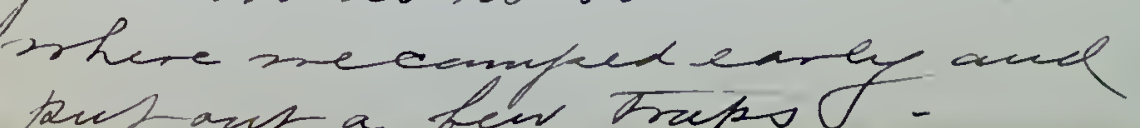
turt out a fer trips. 
Peaner Marah Konmmatale 1 Auguat 9. Jrent on trimar. mhere me compece. 73 ing tich

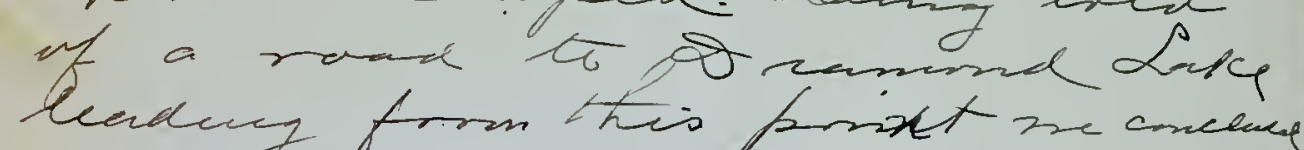

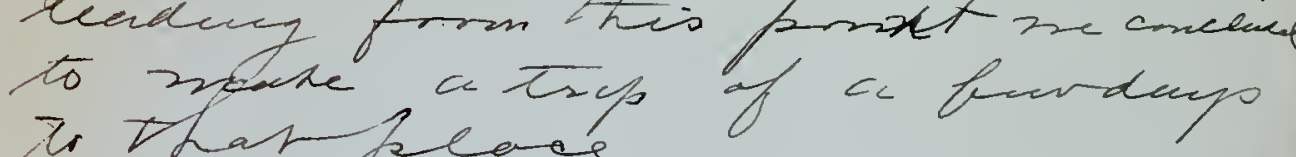
ir that seace.

Ang 10. Left earing and ment uf to Qucanmol Like mhe me. ame traps Drame os set ouk. uis arrectly beterien mt there sm pond Celd Baring or Bacluy as the inhinitymoreace it me passed orer the end of int Dheil

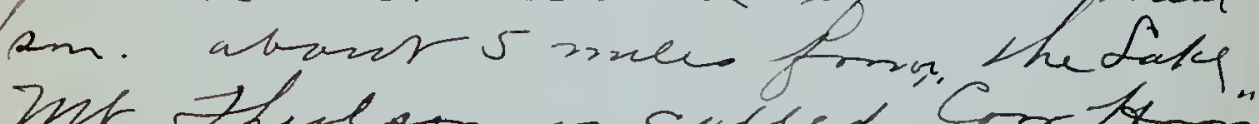
me Thelen thealeet Cortorm by magn sthope of the pead.

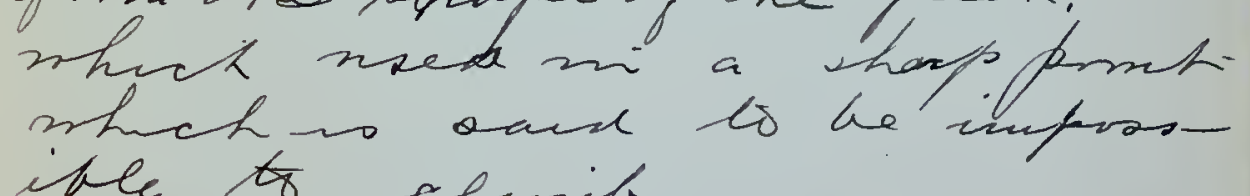
ible to cemit.

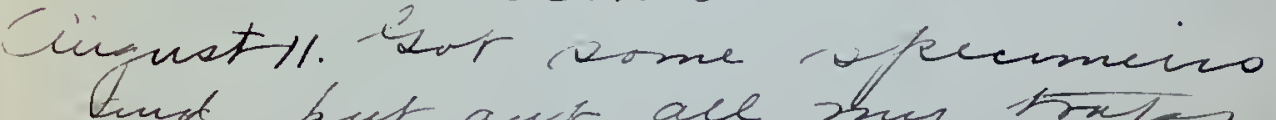
oud kut awr ace shy trof? szathe a lipis to thubcene

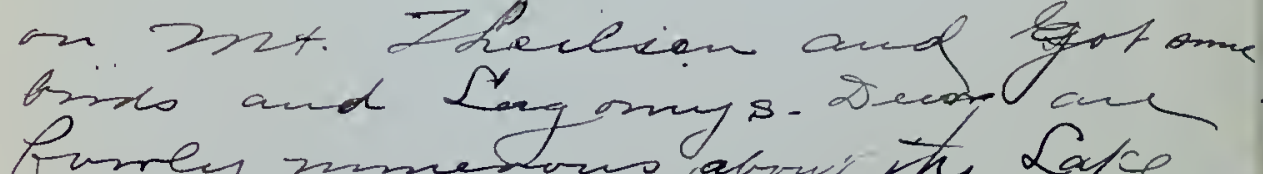

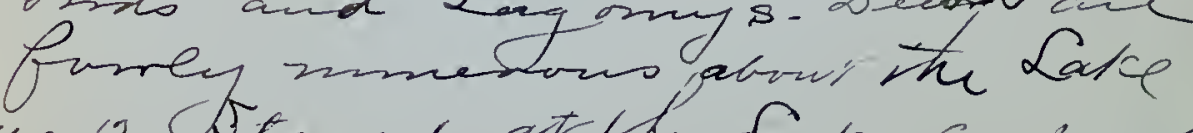

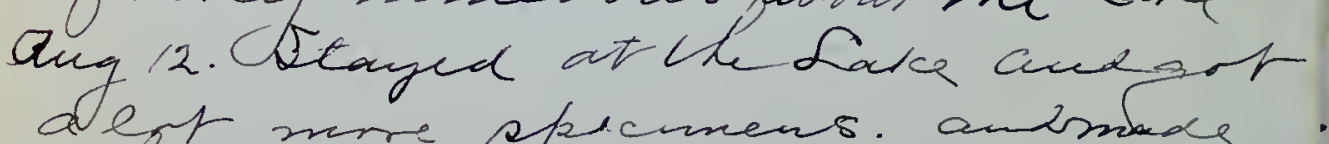
alet more specrmens. ambinsede themep. 
6

Uivg 13. Lift canp quite-earey.

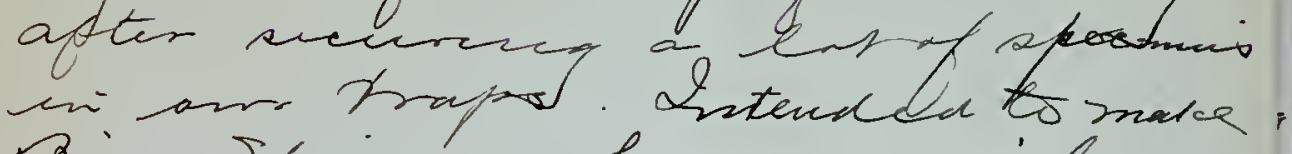
Big Ipitys but nuet mith an arecidendt szer ith summaty the rige mhweh delagedus and she

Quz thi. Frent m to Sand cuet abour halfermy to if lanath Deques.y

ang 15 Liftcanp enrey and

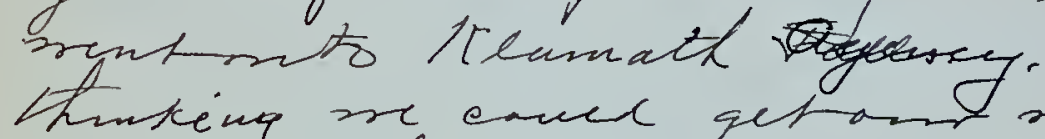

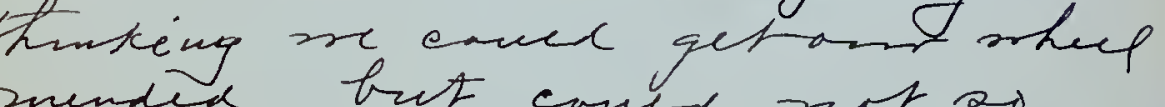
ment wp tor peant so me eamped

Aug'6. Anater wher froid ips sh ite frinovis and leiftabbut

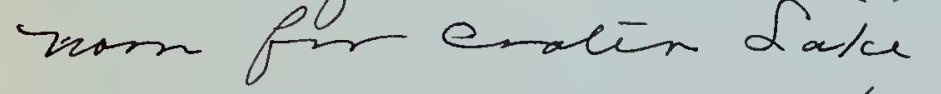
re anmue ovores dasle and frits or merrean $x$ raicey rith Carves party. The trad arrure w Euple of days ahere of ms.

ing 17. Pustowt same trifse and Chita sorrdehuet. Baicy and tchmber smise sicip hullo about a mie back of the Wake and

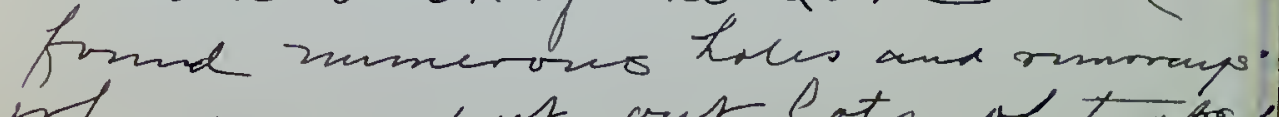
irhe me put out lats of trapsify 
brater Lave Cregon

Aug 18.

made a qovd catch of mannes, set more traps baitex with ineat.

Aug 19. Bota goos cetch of mommal Amare the uf. Ghinged the fration of many trap to better peaces. ang 20. Thunk a tarrey irood citch. and muke c ace the of termon on spermens.

augn' b-t a feyong sy umrecany stul. trapt eet at lhe fort of a dea

angir Cunght a Phervacongs pin *. inde It ras traper on che hill monary in burybustes kgrass of dugt aromid berede a ledige

angno. Ingse agord citch flemo pome

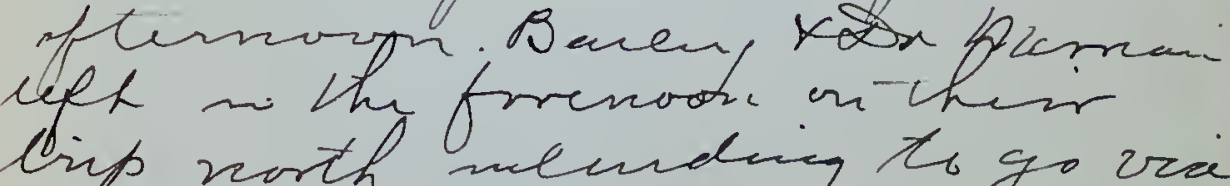
sip worth mending to go vise Ang zet, Changer the prots most if iny traps I.t a fartey 
Pogue Pivervally

Angust 25 .

Lefer Crater Lake and stanel

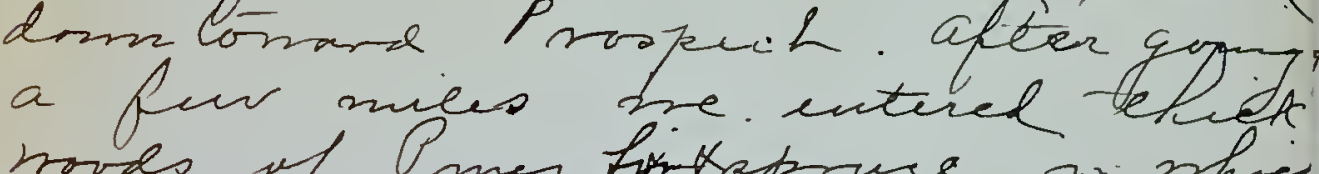

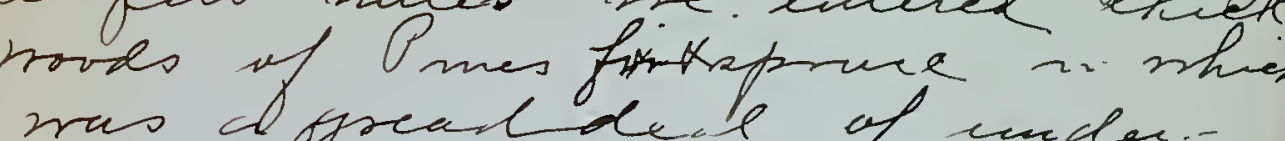
gros th and moseds inched to ght alow and canfeeps at zhade abrut 20 meles

ang 26

Came ace the frrenom

through dence monds of Fri

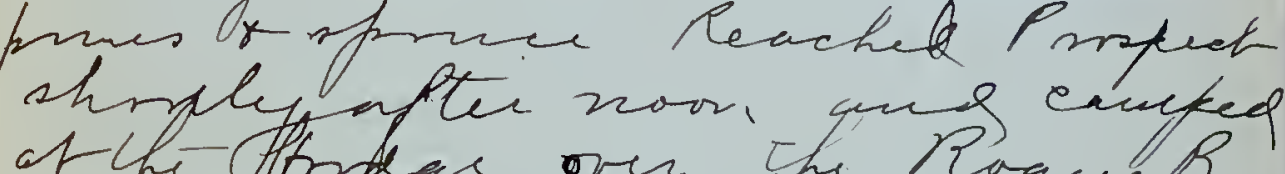
ot the thingere over the Raque R.

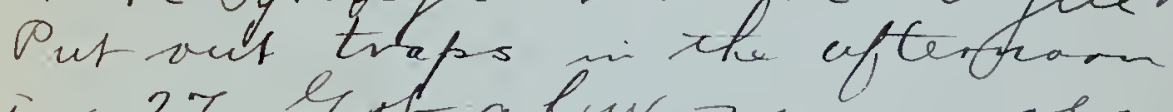
ving $2 \%$. Spt a fur mannale ang lots of traps sonsad. Douglans sperm ahied enmonach

ungro. Diot a good catch

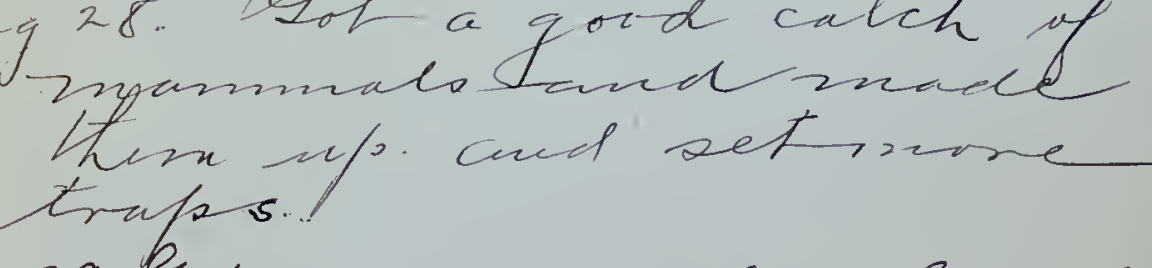

Aug29. Sor some monumer cous mance

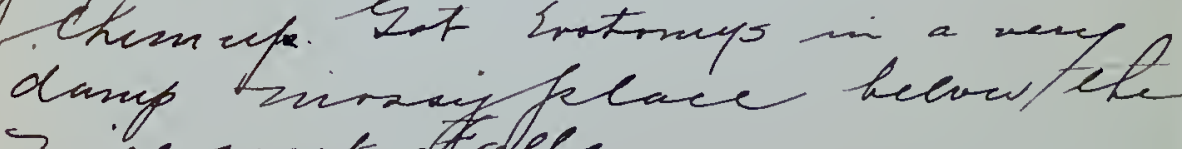
inice creet Foles.

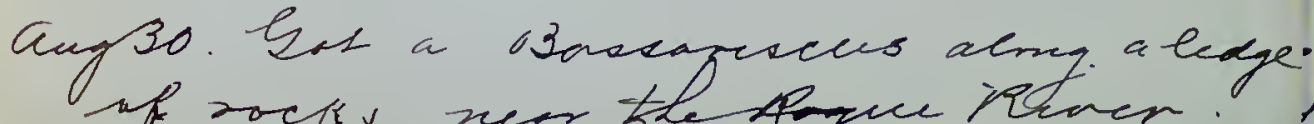

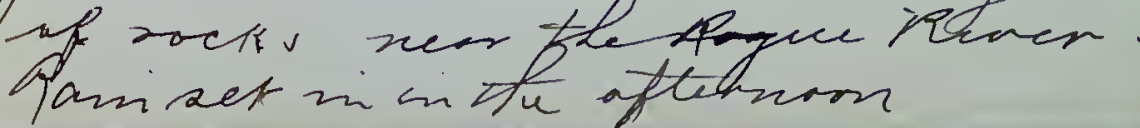


Amra Creck.

Auguats 2.

Pained hand nearey aledens

Lift axaut - wave on mor may Hack

torrand Crater Lake Hent about 16 miees cund camped at a hay inimpicarets. 4 mees from

Sept. I et.

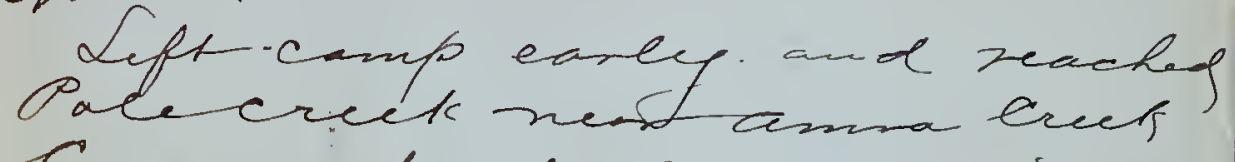

Canon a baut 3 ancek mace

canfo and puc out come

traps.abng ta creets Pre mon thintur frob apeldingtia and setting trafs horther thang 12 a mile finm cuifo.

in the ofereer fut ans

nome anace trafos and

Jept3. Gueght 2 apeodontias and a lot inre specincues. Het sme traper far feyniz

Septy. Peinamed at pace eseek Lot a fari catch mals. Auncid xrmeni chafer noves Sur a martiu juarbefore zughtfall fut 
Sept 5. Pemaind as Pale Cuell all day lart a fori catch \& mearell. Carght it in cit. aptodontia romraymi thick tank graso brodring aue m the flownom. leanght a nean if mi the eame trofp that cang to me the preveres day indunter to sucte. augfet a Heuratichies arog bunde pole cucet. Fle

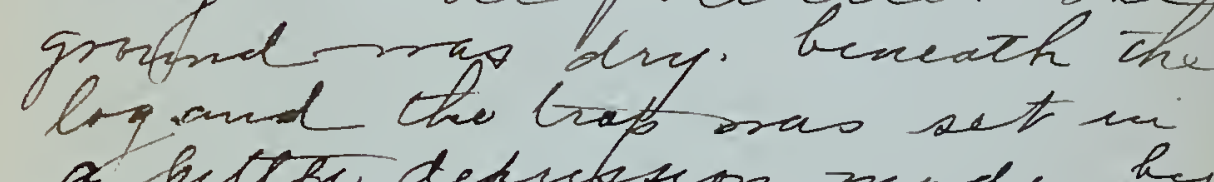
The hand defutesion mende by Lef canp abret now ace Reached rort Kemath akos Sachek. Sew Tammastomendi atrut Ref may dom and caw a chipmund. whech ltork to be tomsende' near the

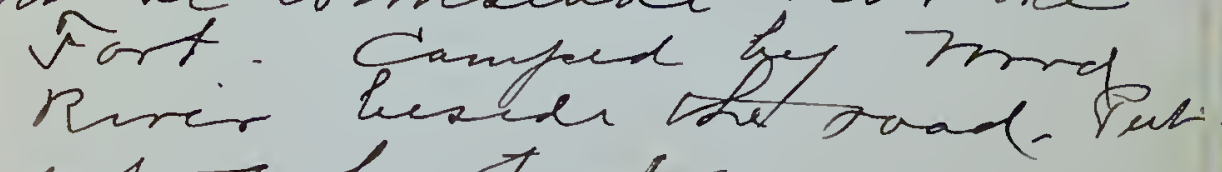
aut a fewtraps.

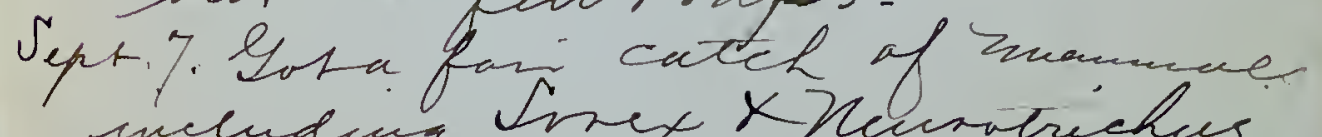
incuding inex $x$ Newriziches Putnet Auretraps fore chife numedas itto ifterion 
Lefet 8 .

Canath

Inade a lange catch ande

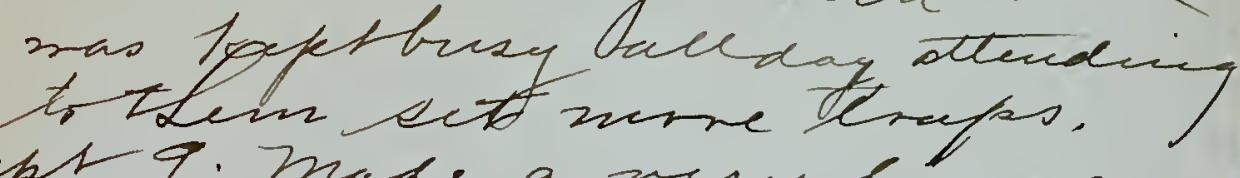

Sept q. made a nery

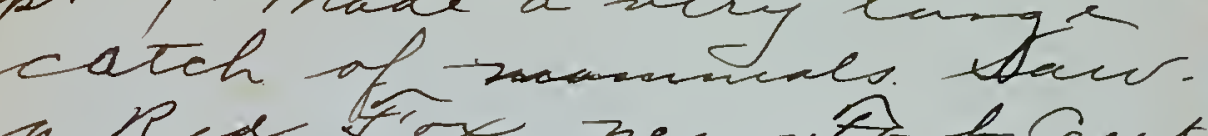
a Ped Fo near- F, L Guts but did notweced w sielniy it.

Sept 10 . A carge caoh y mannmer. lert a mhet beeend dephyrap on Arot crege about a guarecraf a muie caboue theroad

Sept11. Sirt purcher veuraticicho neor whene the firct mait Lawen. Ltwros near the band of the mire pir a rather dry Reteiaim and the trap mas set m a place grapaped acut met the hand at the bare of a bunch of aeders.

Septi2. a large cotch. Art2. A large cotch. Irt mother
heuratichuo in eame feace as the
vithers.

Sept/3. Int afair cateh of mancuals

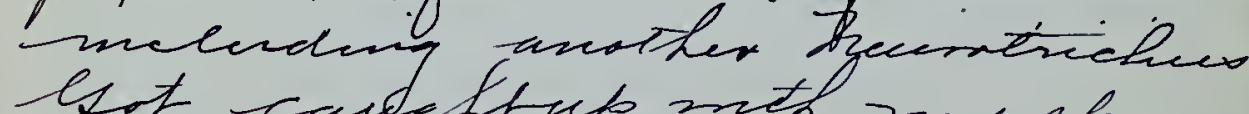
lsot cardatiph meth ny stum

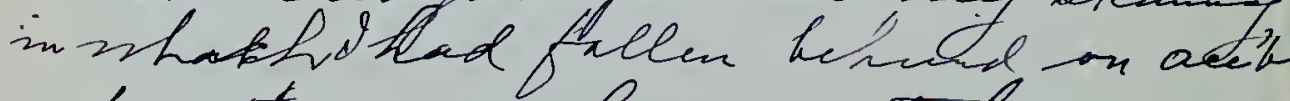
of extremely large eatches. vept. If. Interded a leare ther. nugnipl but hod trowe geltury the hlow so deid nut get andy

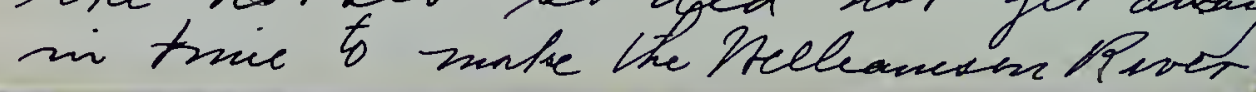




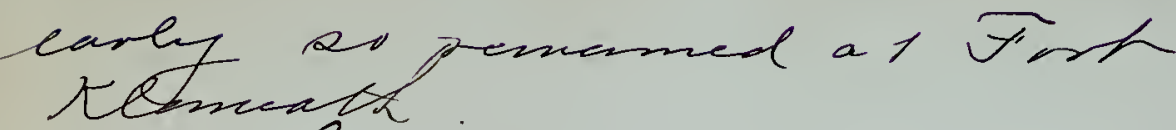

Sept 15 lert

got to the melecteon paren guto earty cure putan iniee on the flat abouta

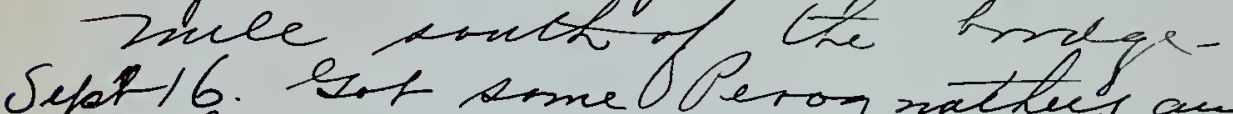
nhite forten nue ghist no Dipo downis Znt ryp trapes and rrect on begm the Lake cancfeed earey

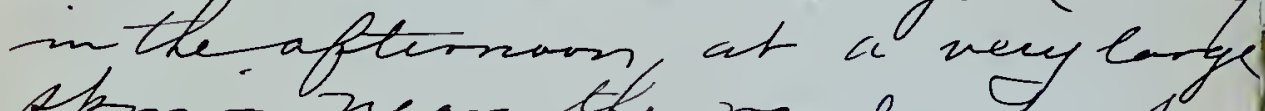

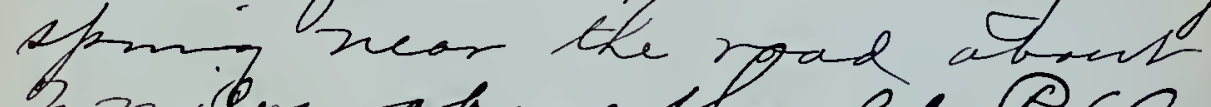

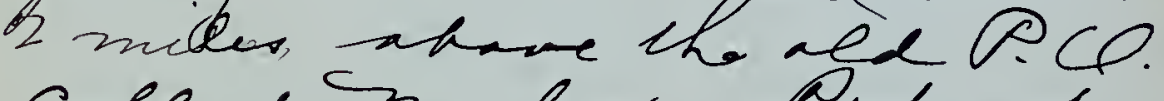

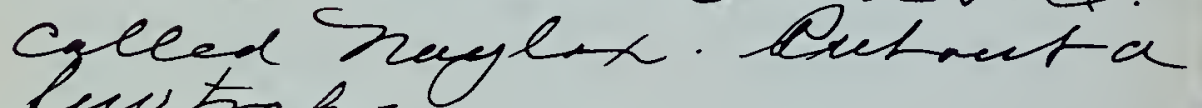
Pect tabs 5

Setert.

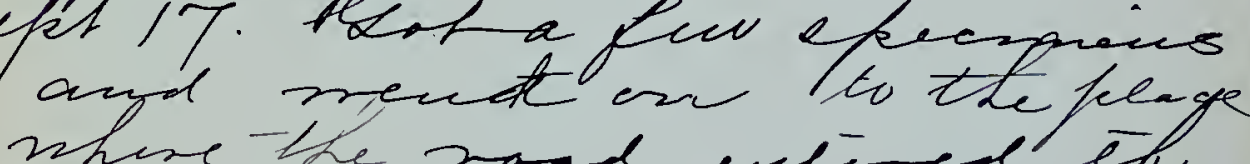

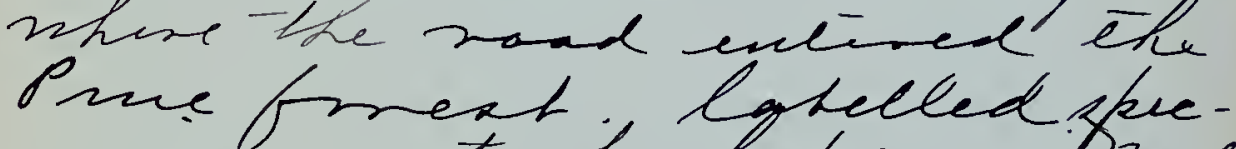

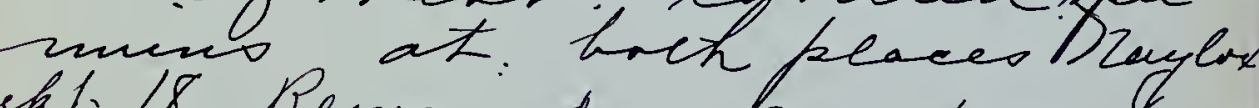

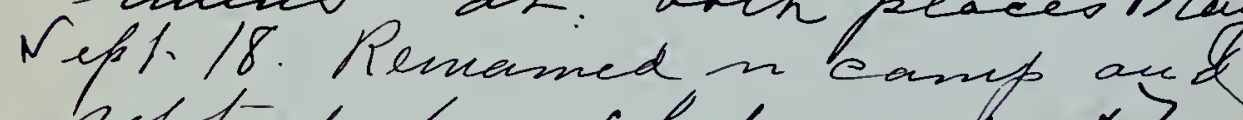

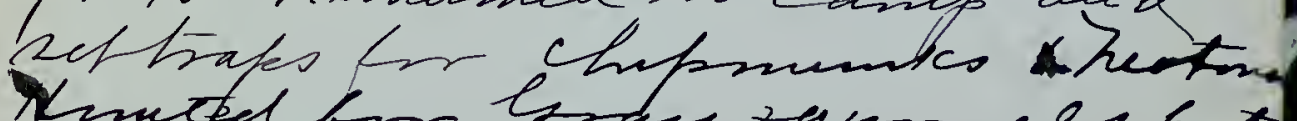

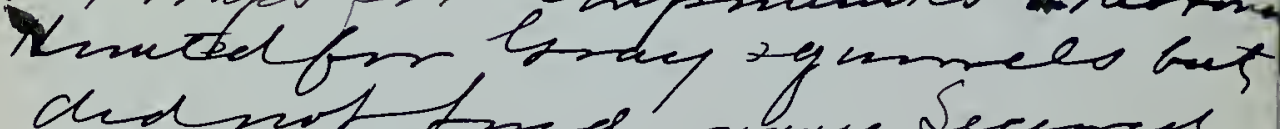

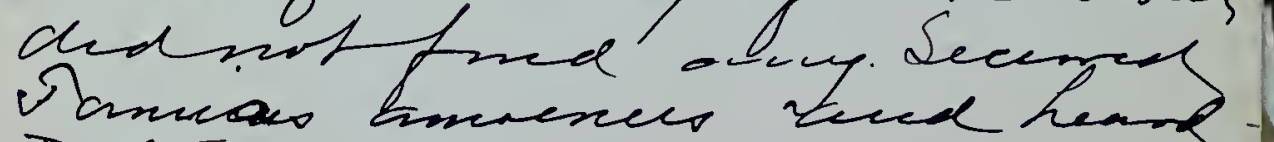
T. Trmpacudi.

Sept 19. Lort spganneso

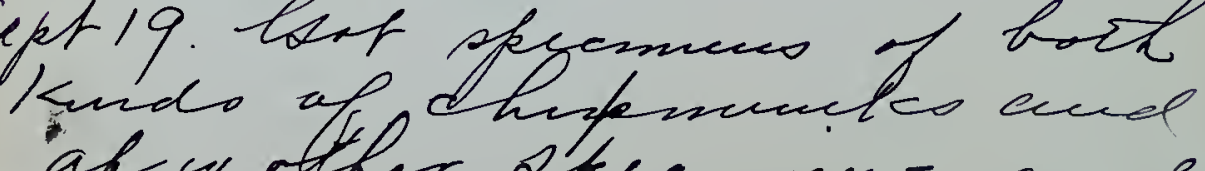

- afiw otther ofecensens lift. gurte earey for ken-ch vraels. Snewdedto hunt for 
Deayert. Reanath Bacui

chiprzinges wi th chaparrat

* all but as it fuad ramed

nearey acect.

and mas mach

volence mas otergte to

ane thep. Heard aze

in che chapperad incei

me che chapponal stuei we

oy aftiman ane after

rut In drom che valely wout

10 snies ave canjete in

Srat Pyien.

Septi20. Out aist mpry trafos

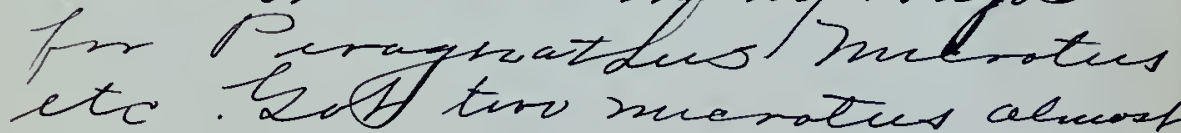

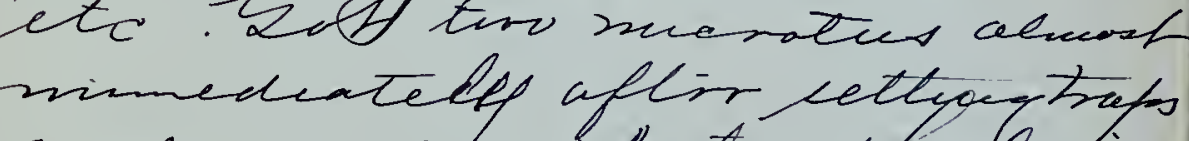

and on confeledturgthe Sive

mone. Set a fw steel traps aber and saw frme rew

encuel mofit. trueder stheh inuy be. 2. celatorensi

Sept 21 ded sat have sucech puecens but put out nure traf's for chepmonk. 
Keamath Dasin

Deper $22-$

a Lew demedyate and gut Ifemenew mi mud brap

Sefs 23. Staw a Spensphelis hefdnge and ghoctred it fefr a ene trive. Iheyare

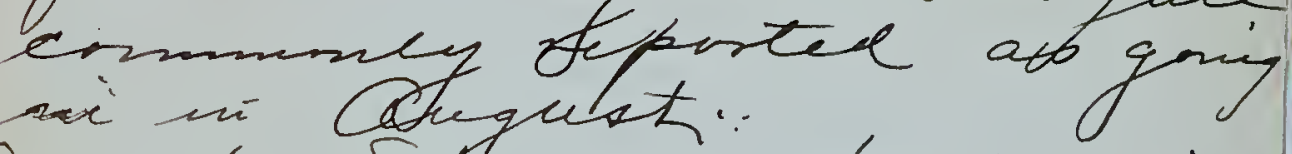
sai ni Sugulst.

nur keaces. elexp trafos wi perafnathes.

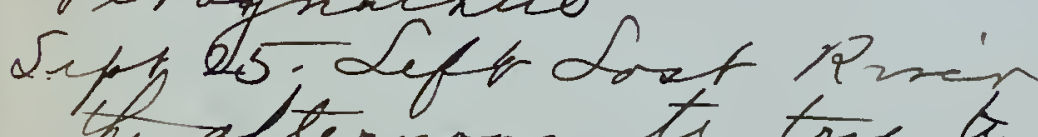
bele leventity to trafe a nigh or twoty. Cad srafe a

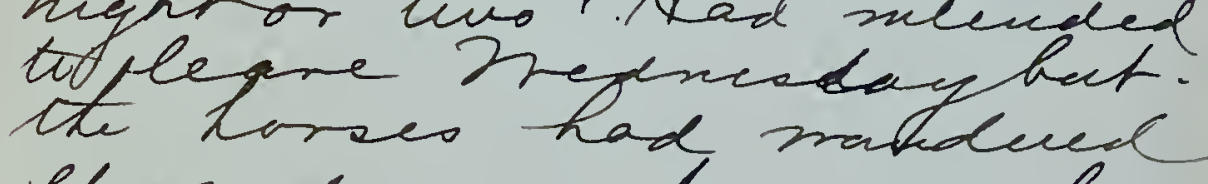
It ayd nere finally found frice -

Syt 26 . Hewl dinn in thenest ndi of O we daice a shorb distange of nacto ohse - a ledger And itei place alona wiel fitr trafoficy putrut all nuy. Koffor fot kert mux 

bujekmu sole. Angue a crowa olher fine negt of hertine wit a the sfok.

Depr. I7. Preleed uf me traps aude a faricatef rof

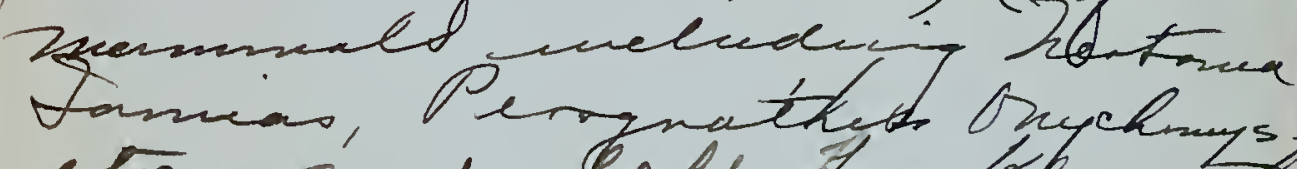
tre. and Keft. Kkandi

tivee bafm dewit. Cuep arrativine jush arrived. Hace armaly munts to stre the autset cict if C. CU. Braudon the than spmigig caut ing grounes. virtff ar finm Rept 28 . Inade a abort top

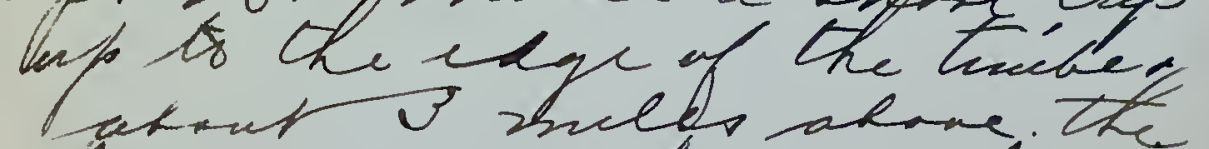

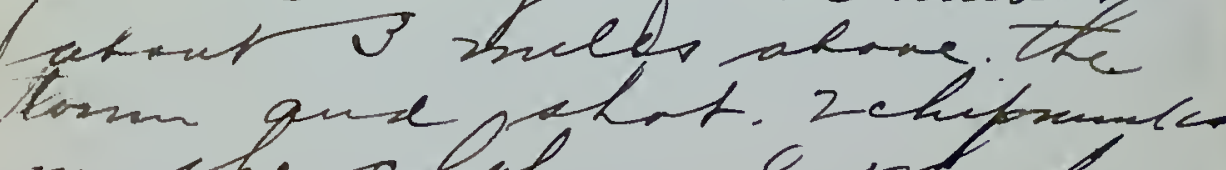

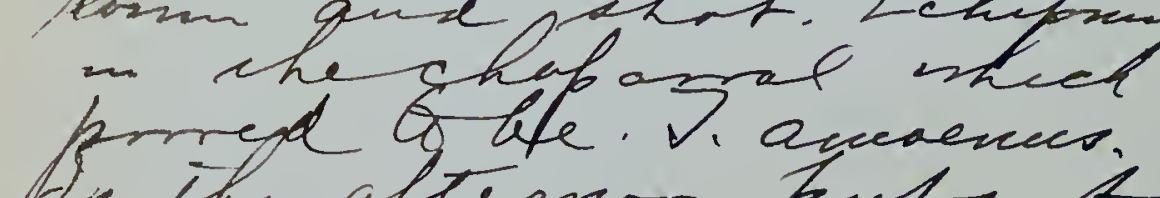

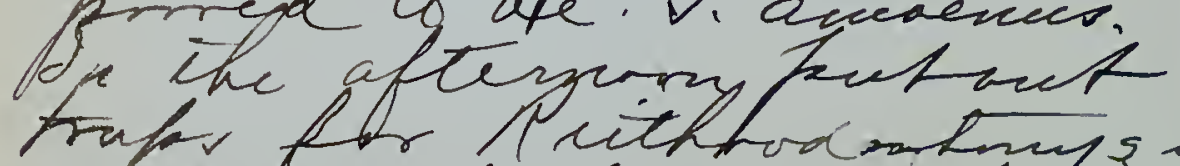

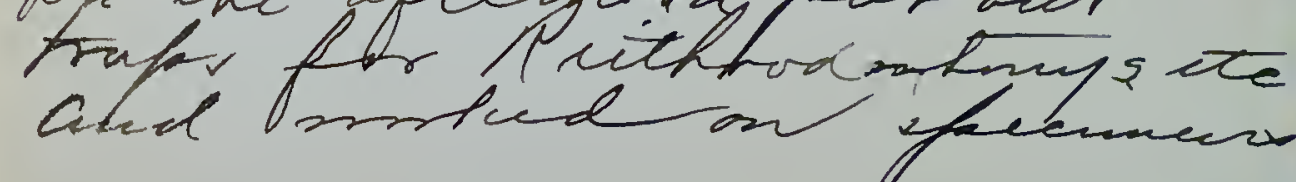




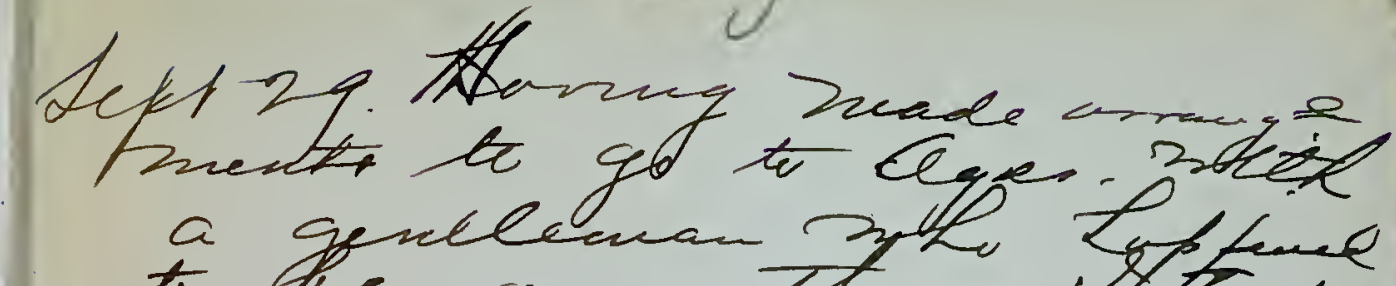

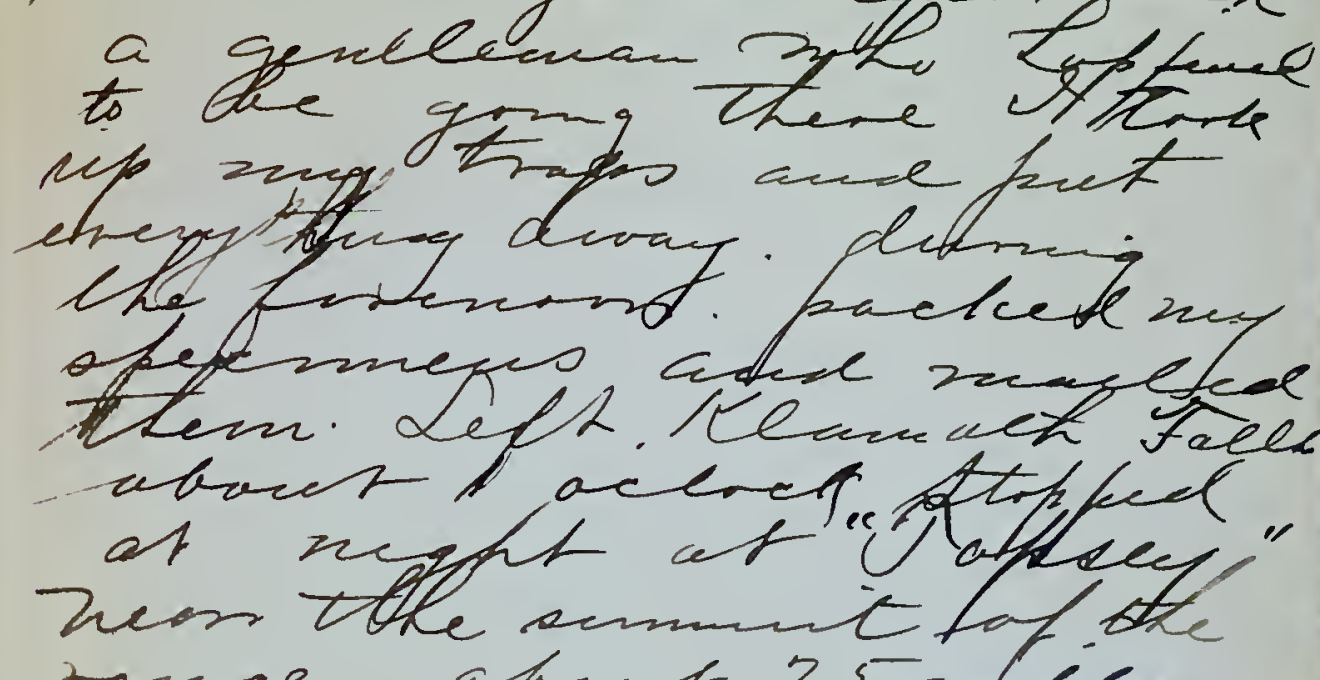
nem the cummut $t$ tofices fow mang chif nilles

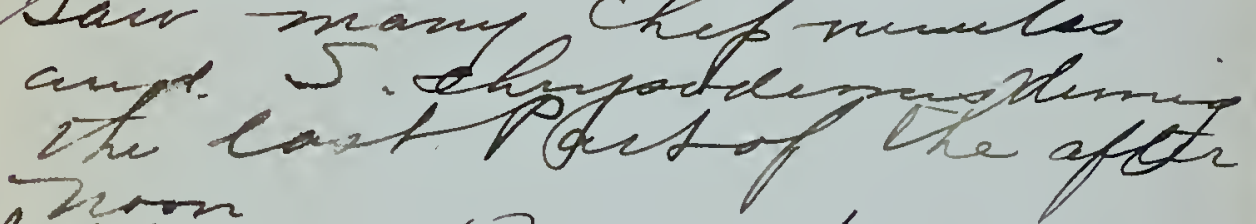
Lepisa. 13 zan to sec scurino fresa and

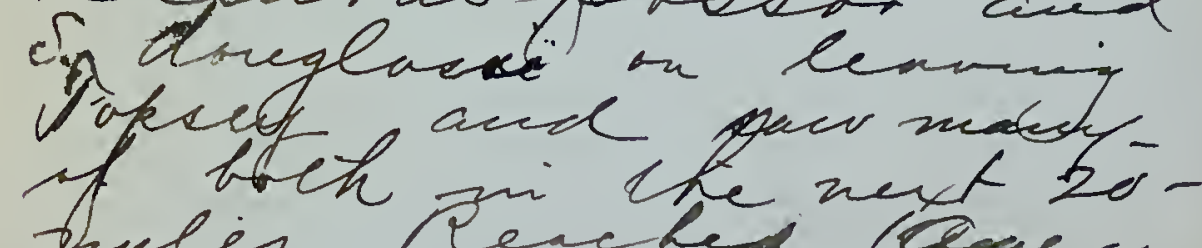
mulis pincke neytenosme tuie aeforre delek.

$$
\text { 2. a. putle }
$$




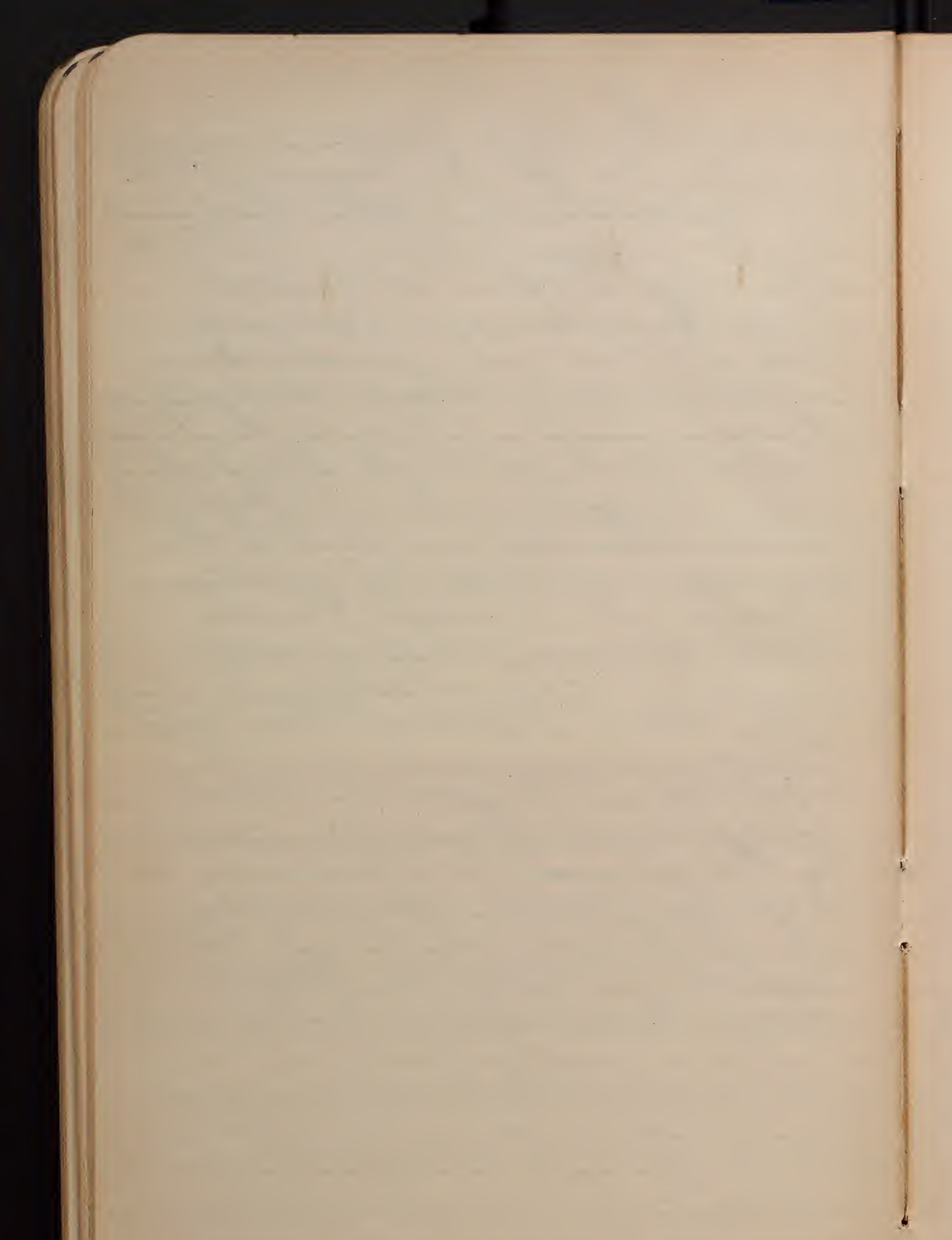




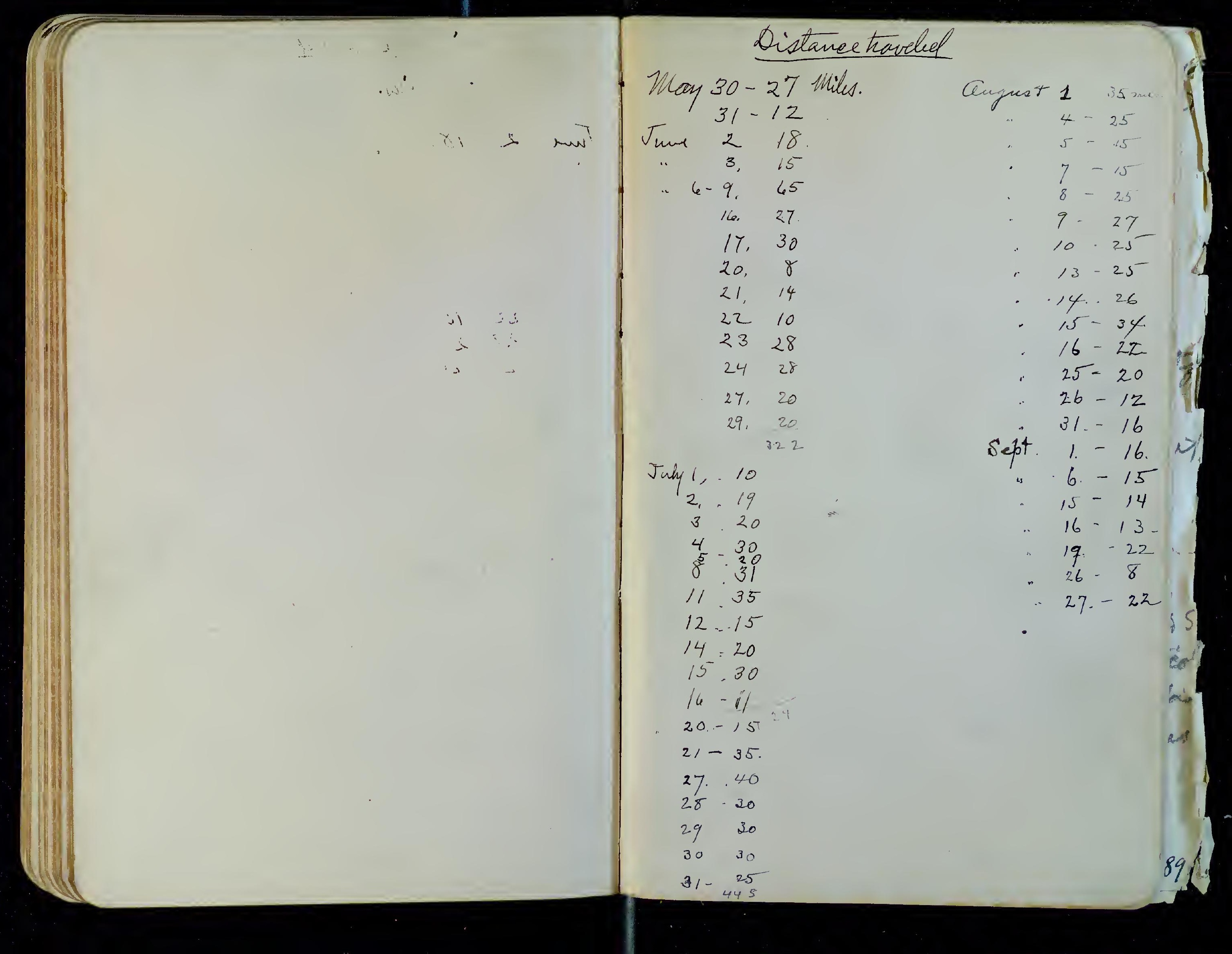




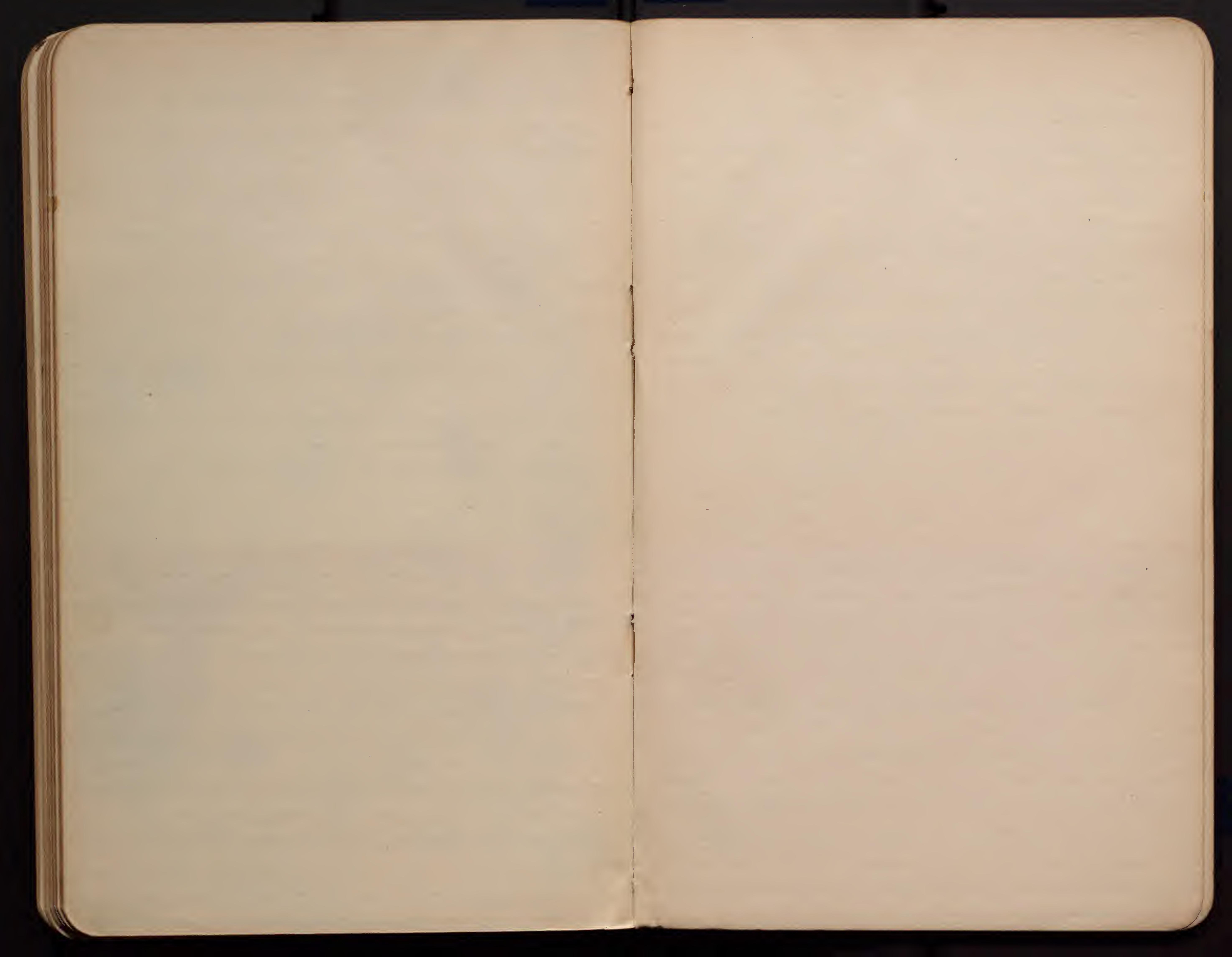




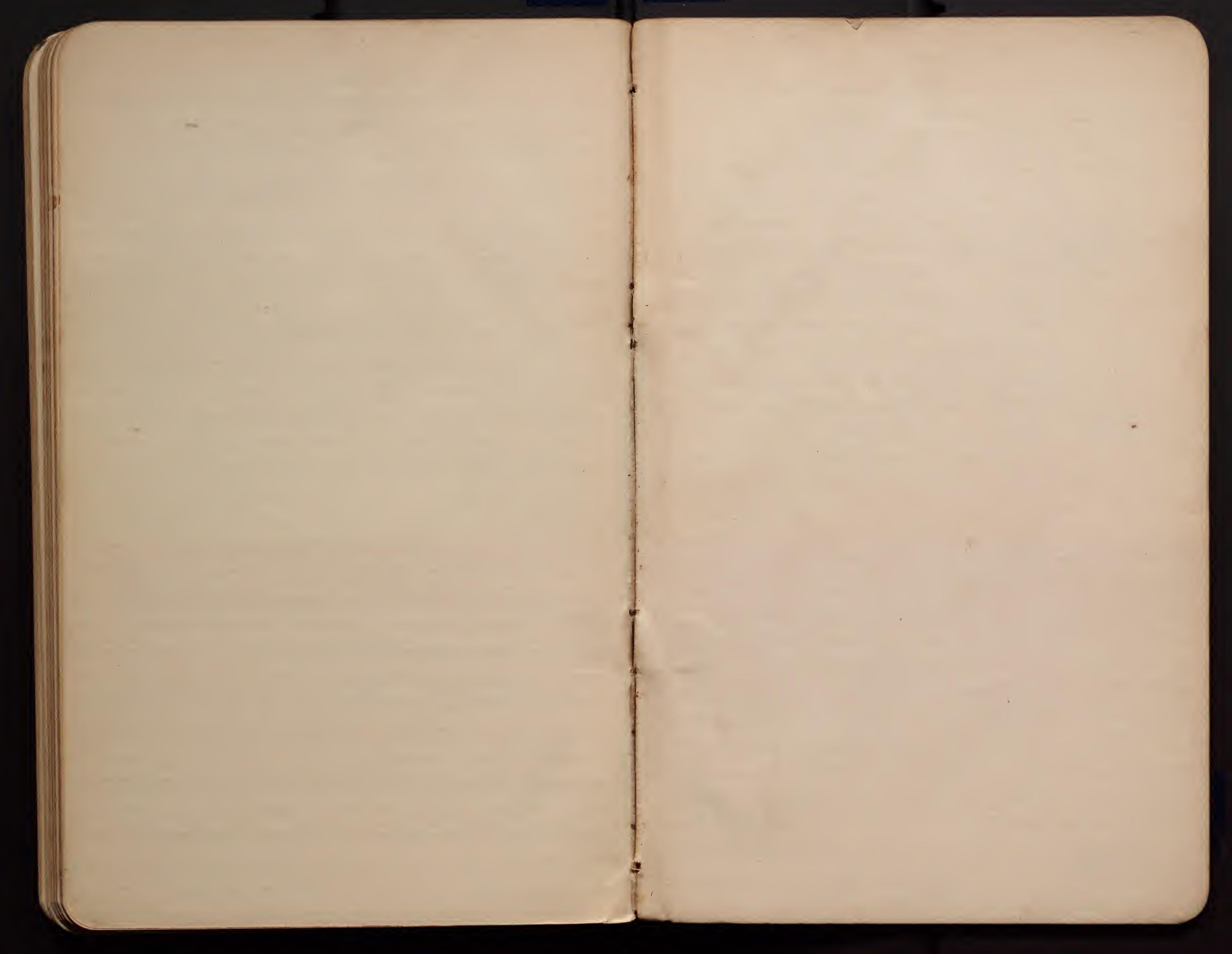




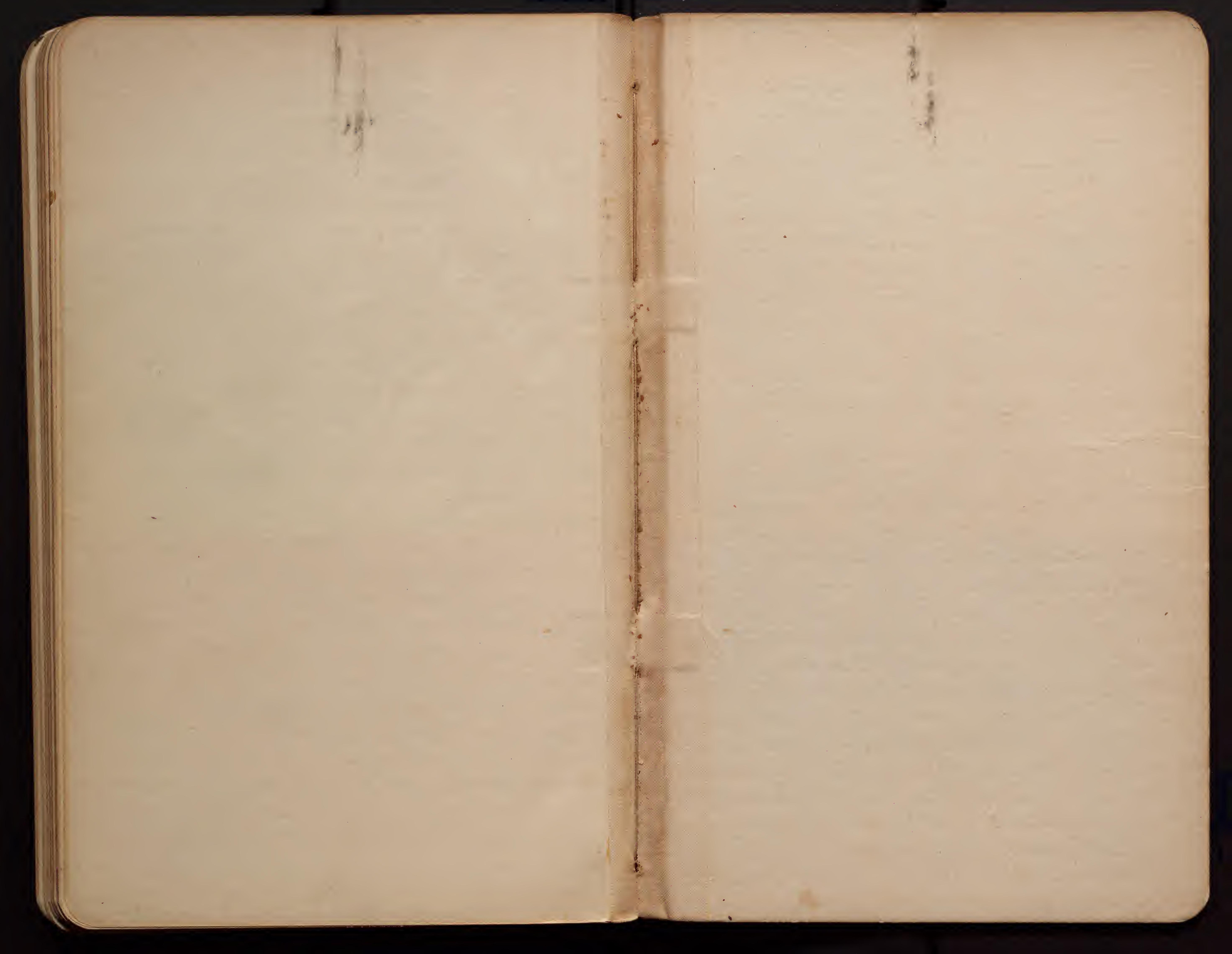




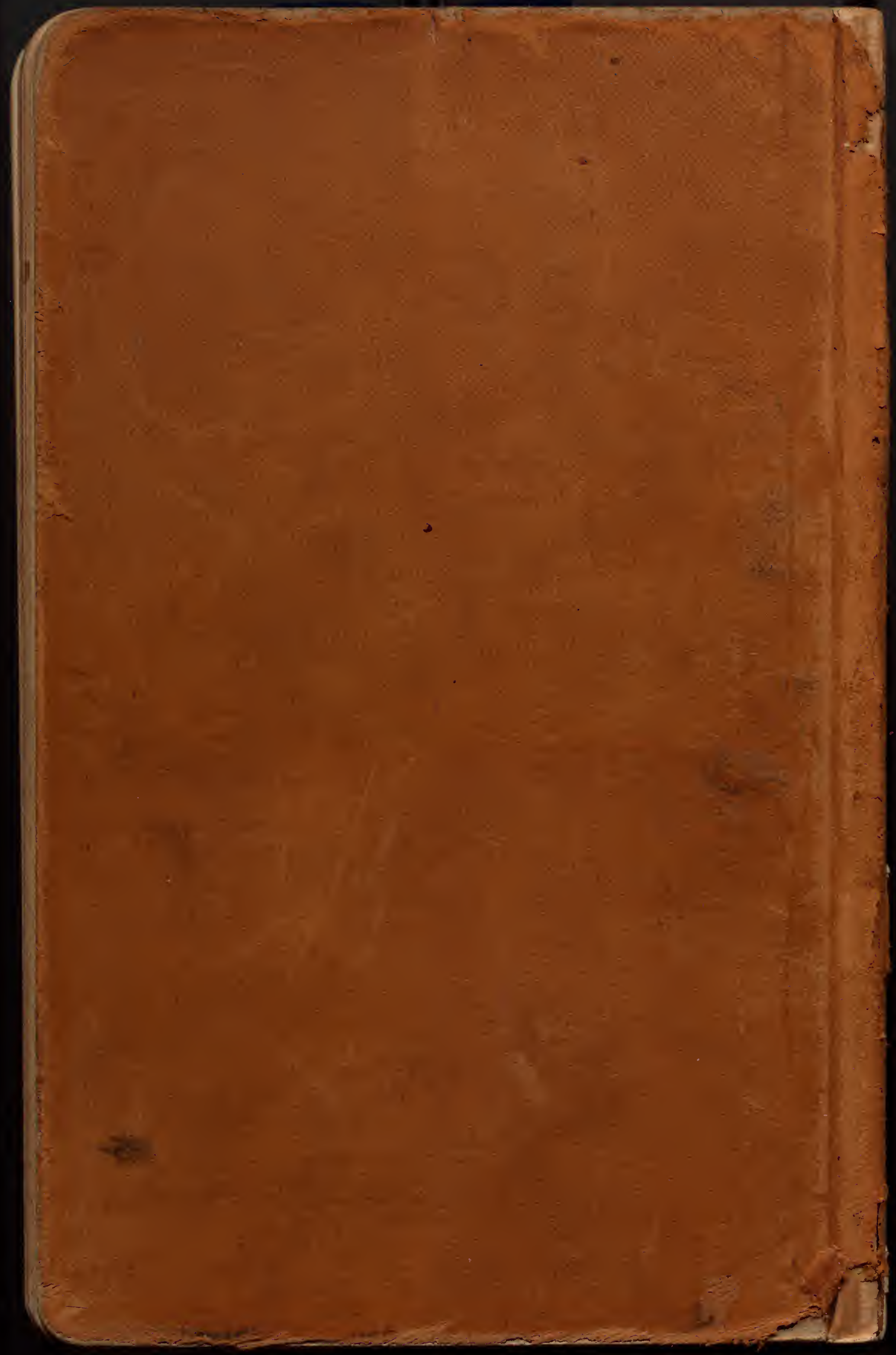


2um 25,1896 , foumd ofth

Camped of "The Zaken" on stum lits. 7100 fat, 22 miles from biamond. 2 aspien.

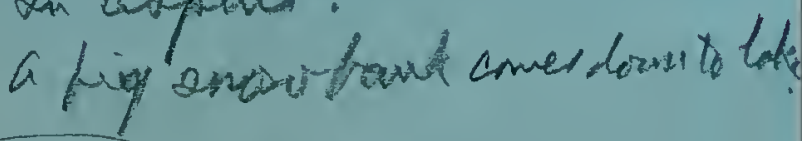

Cavadiand higins about croospt

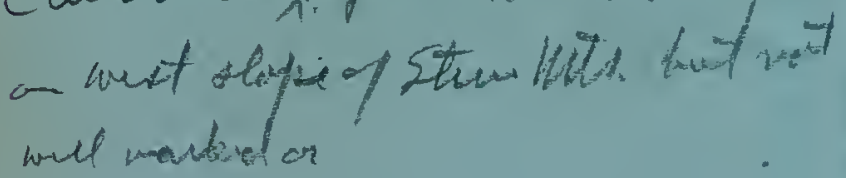

Julyes canpuden aminit 1 stumino. of 9000 pit 2 sumser quanstitien of and -

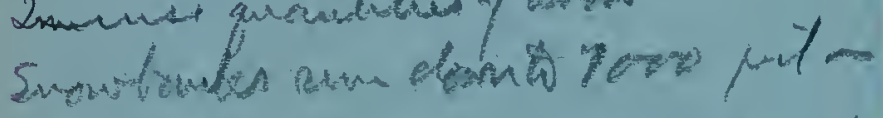

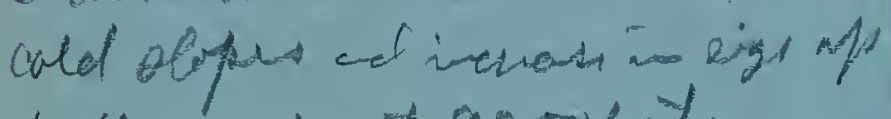
t the suniti at 92 sepent.

coppens ane of to seore pid

Juhes down to lok of 81000 pet

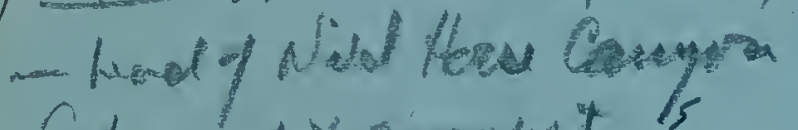

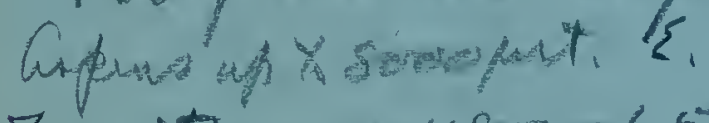
Transition zome 4800-4520 5.

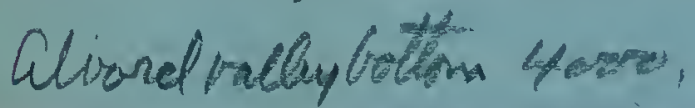




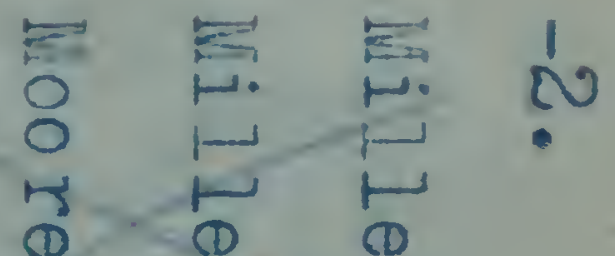

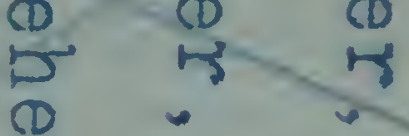

$$
\begin{aligned}
& \text { : } \\
& \text { \# U ? } \\
& \text { - }
\end{aligned}
$$


Wht Hood. spt. 5 - 1896.

Wapaita - 1800 fut

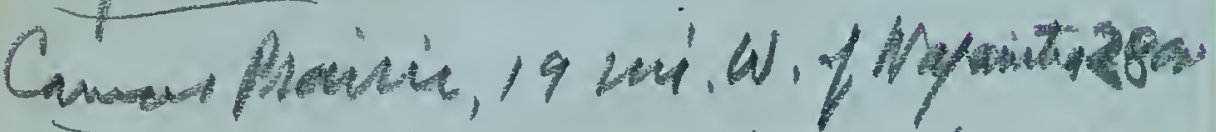

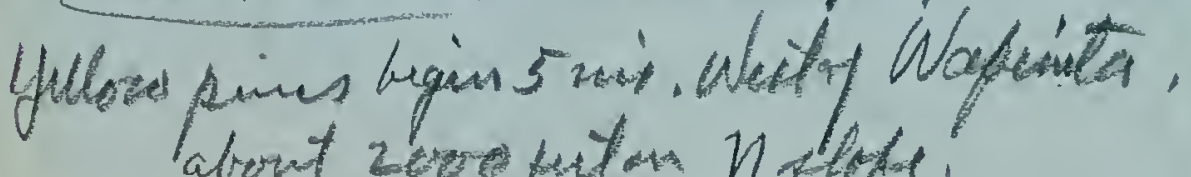
about 2000 pitas nalope.

Curdecingen hequs 18 miks westy

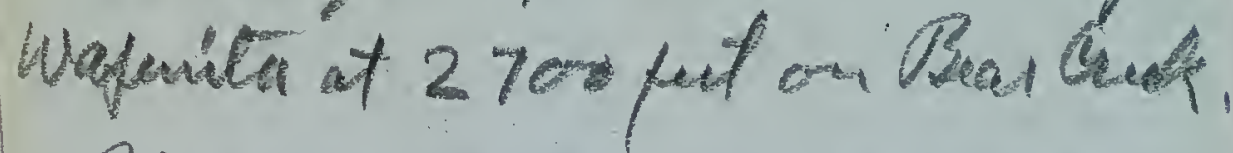

Phing imenyana; montieda, Piera

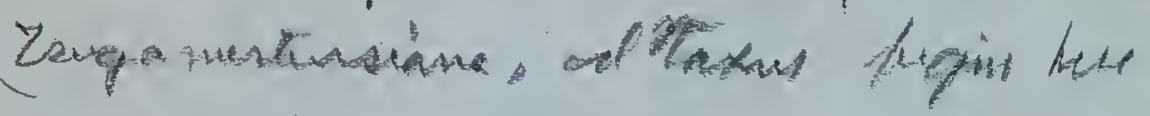

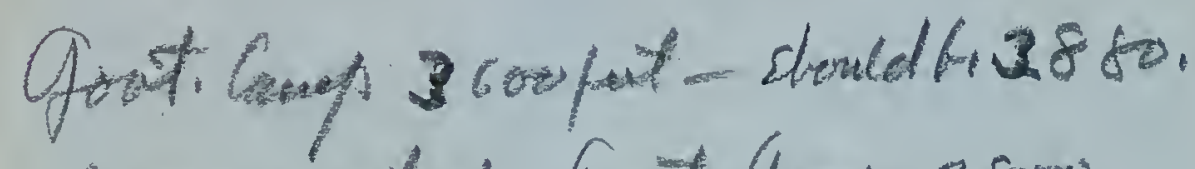
Redqu wat of Gnt. Comp 3 soo

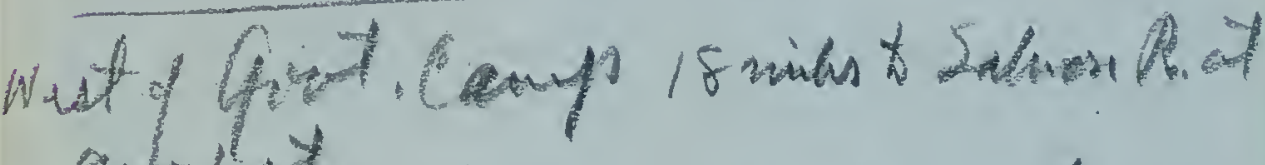
900104

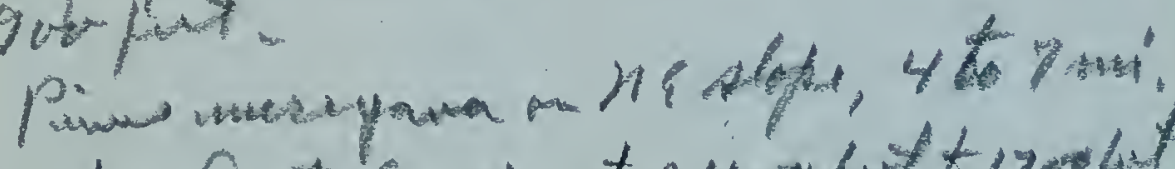

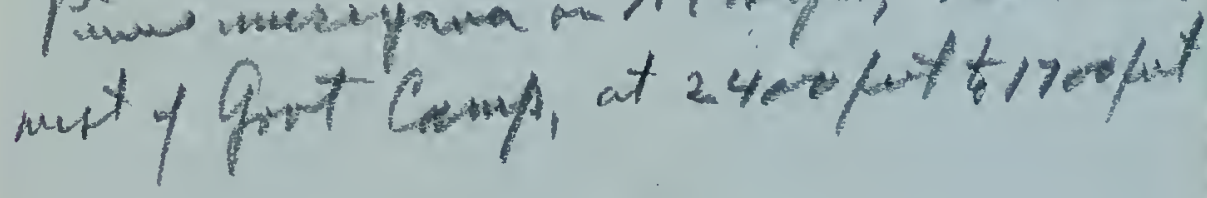

Fem proumalis oftll. 1896 . 


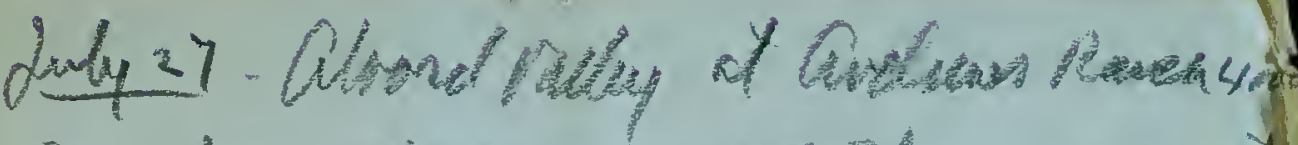

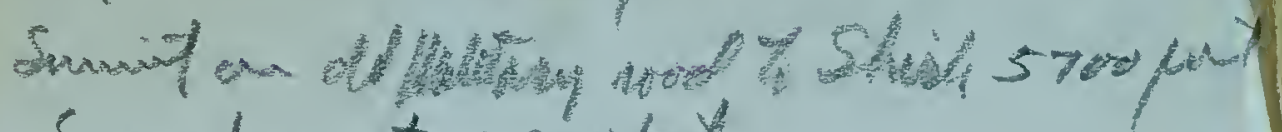
Suead anut 5500 fart.

Shich in Gtolow Dally 4500

Loth21. quan Valley senerpit

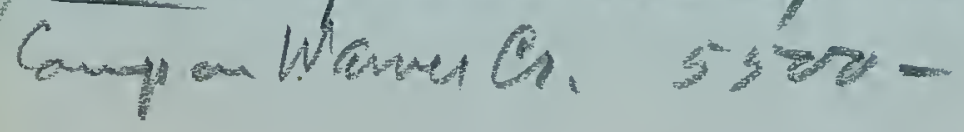

Jahl 30 Smmity Koteceps nowpe. (coedt)

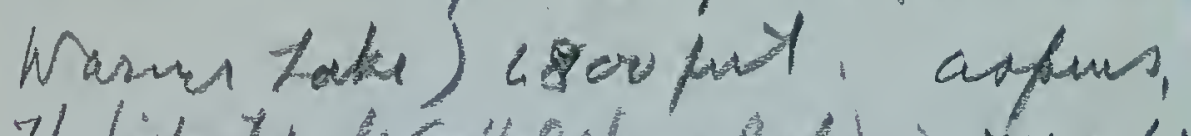

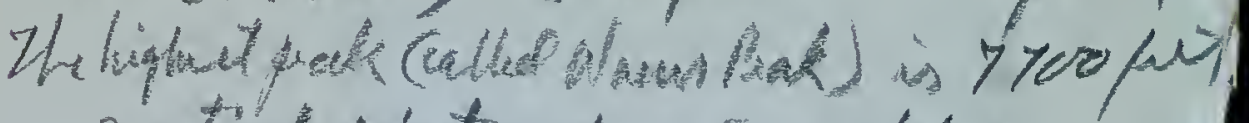

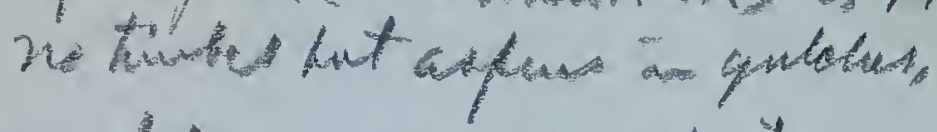

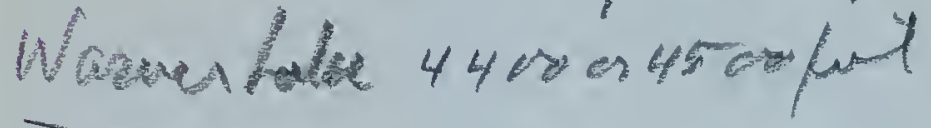

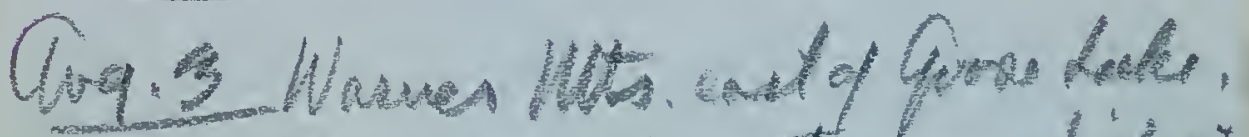

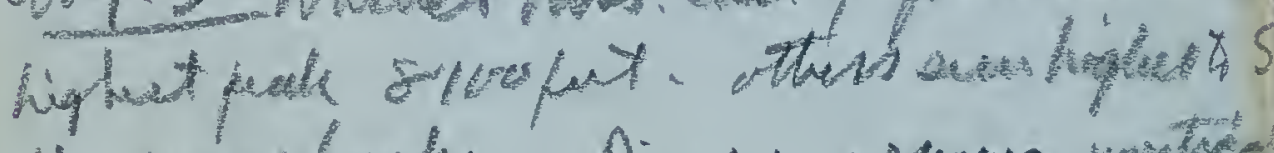

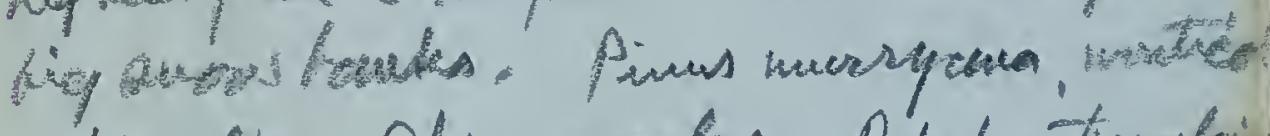

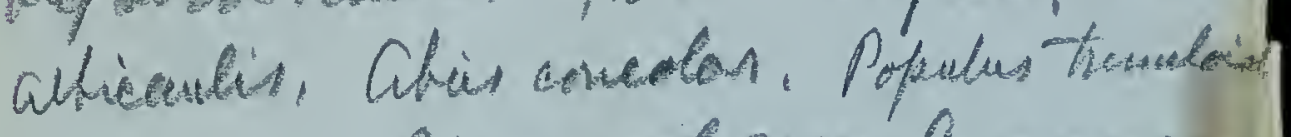

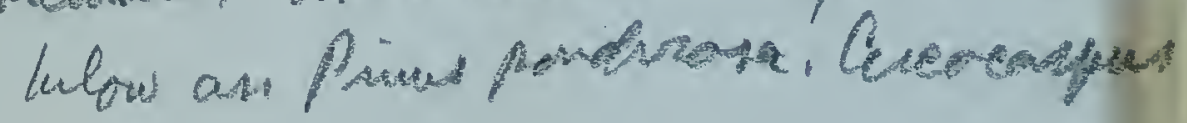
te.

goare foles 4 sare pat

Goural C.PIL. 189 


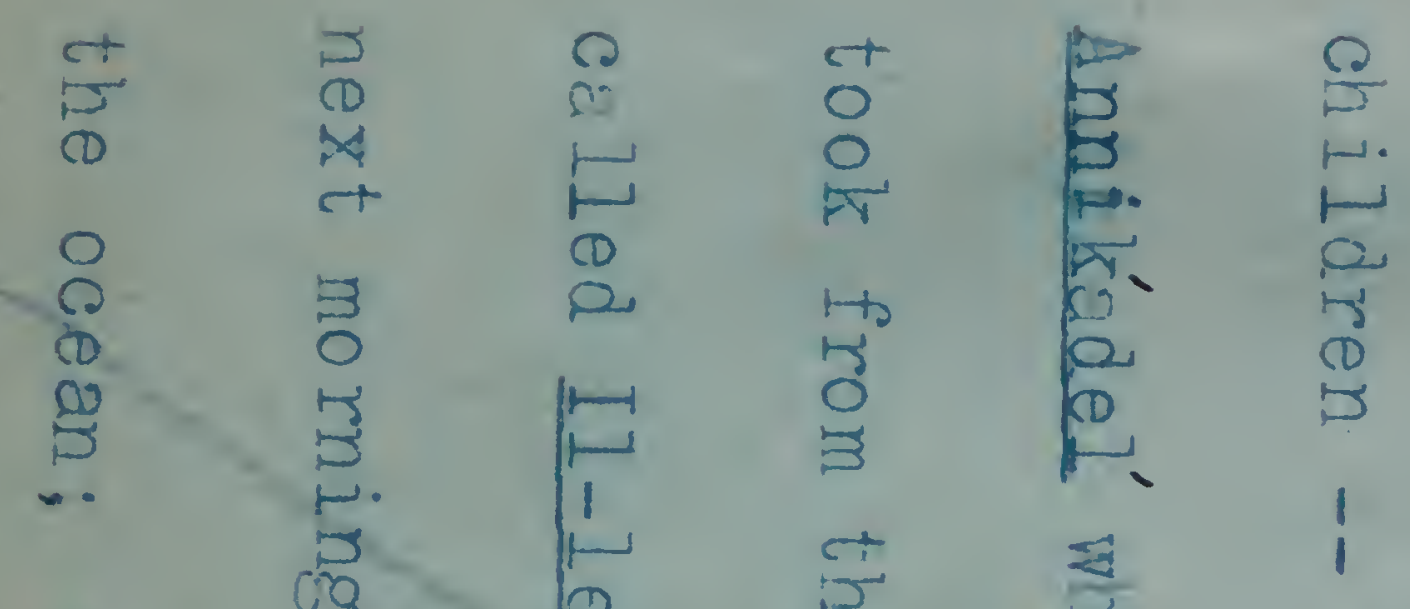

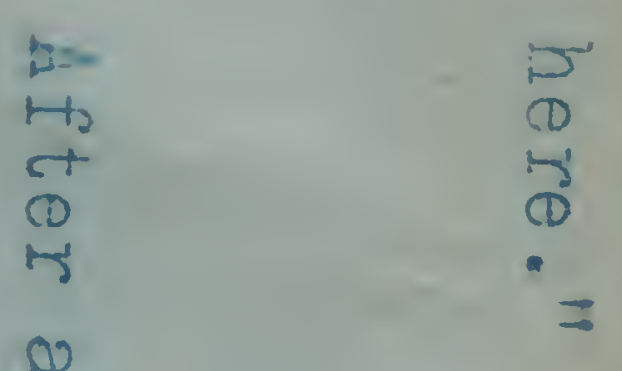

0
0
0
0
0
0
0
0
0
0

$\frac{4}{4}+\frac{\pi}{4}$

or

is

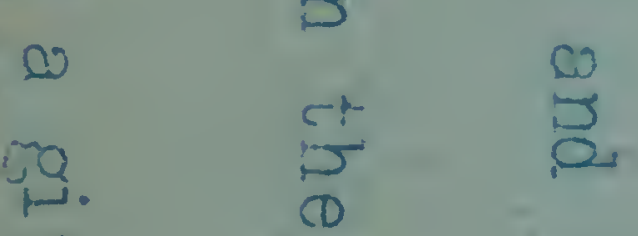

r

$\mapsto$

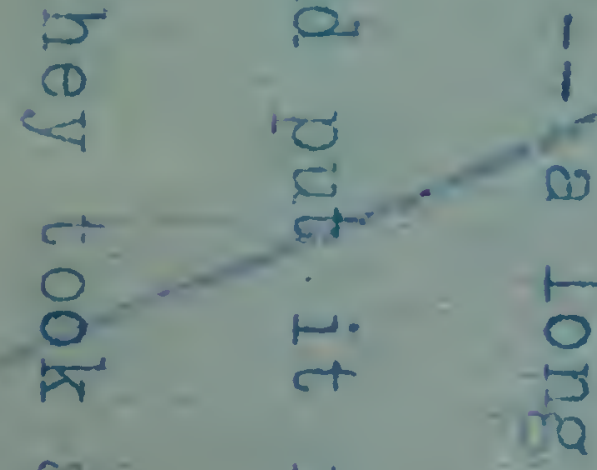

[I]

8

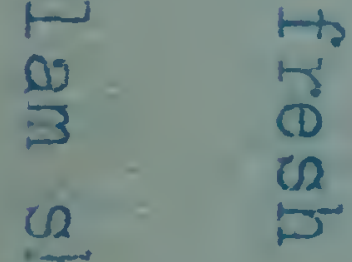

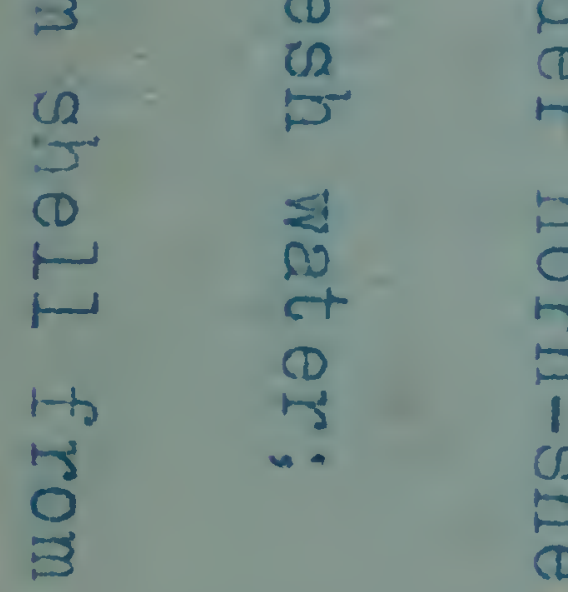

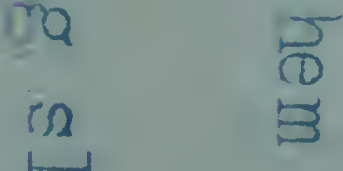

혼

$+\frac{D}{C D}$<smiles>[Mg]</smiles>

co

tos

त

ํํำ

客

官

9
9
9
5

莺卢

Q

$\rightarrow$

$\begin{array}{lll}0 & 0 \\ 5 & 0\end{array}$

$\stackrel{8}{2}$

ग

$-4$

孚- 0

\begin{tabular}{lll}
0 & 0 \\
\hline & 0 & 0 \\
5 & 0
\end{tabular}

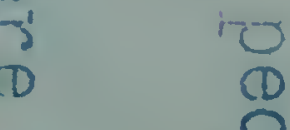

a)

㟒

号

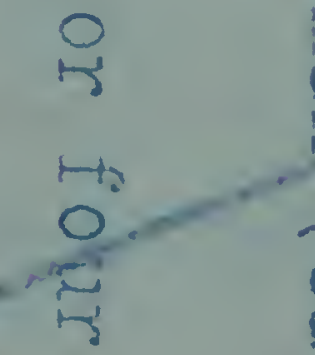

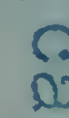

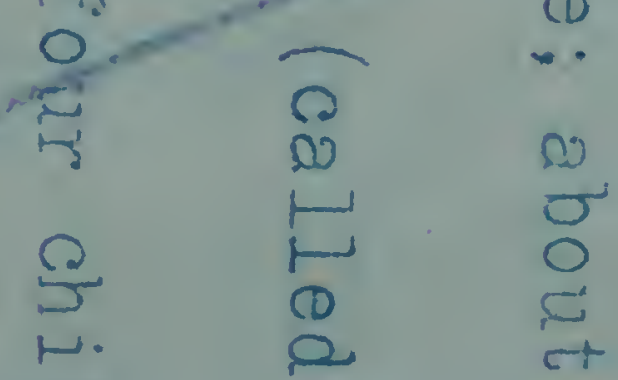

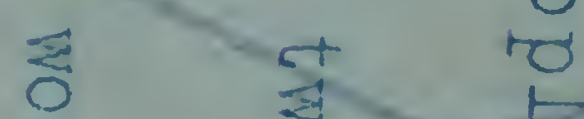

$\infty$

5 an 4

¿

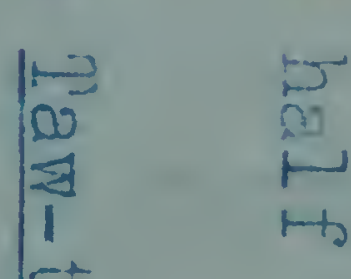

क म

D

登

范 管

15

8 专

(I) 4

+

$+\quad$

$\infty$

(1)

这

a

1
3
3

के

$\frac{2}{0}$

$\stackrel{P}{*}$

$\stackrel{\substack{3 \\ 5}}{9}$

Q

H.

$\because \quad 0$

os

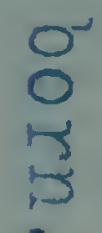


Catu Lole Aup 13- 1894.

Candiangere stare-70io 54 Hudravianzona 7000-7100 Sel.

crupion aim of lader preor firt.

Gaviond Lale

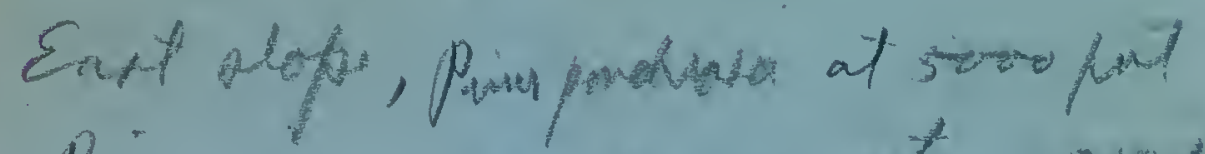

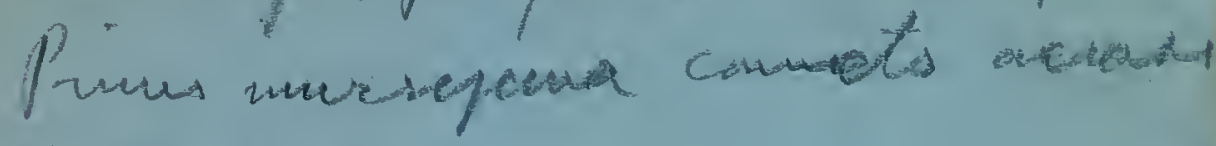
t Punlinas -

In founal y P.tIll, 1894 . 


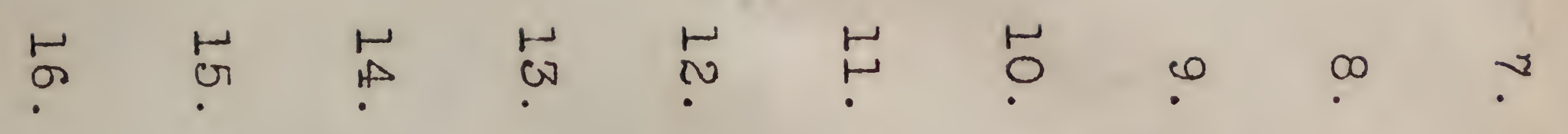

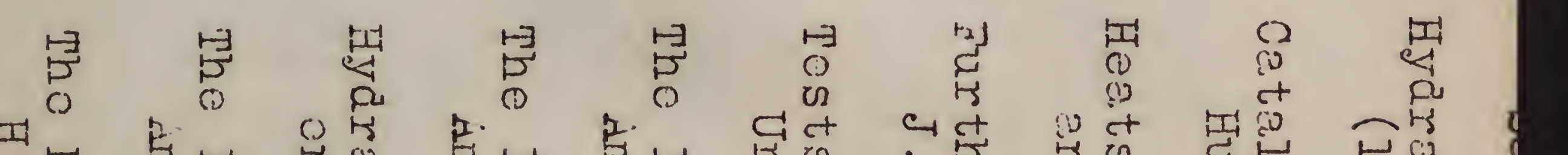

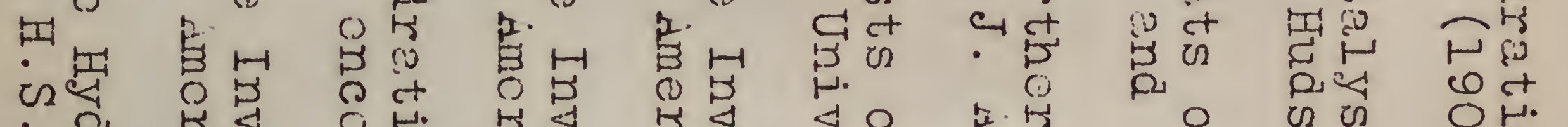

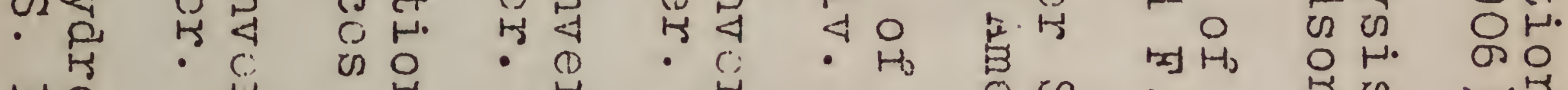
म० मु म

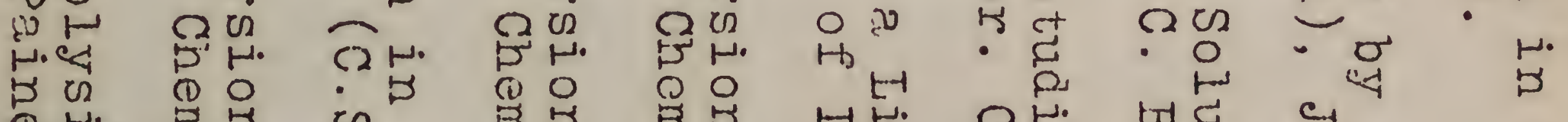

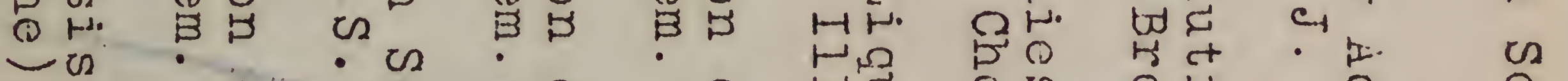

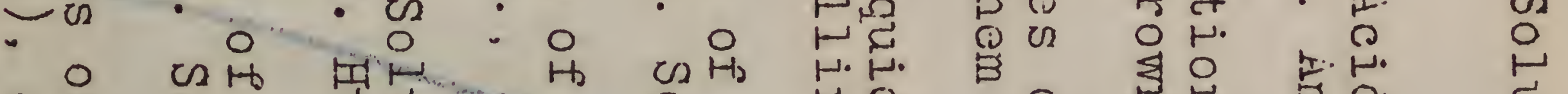

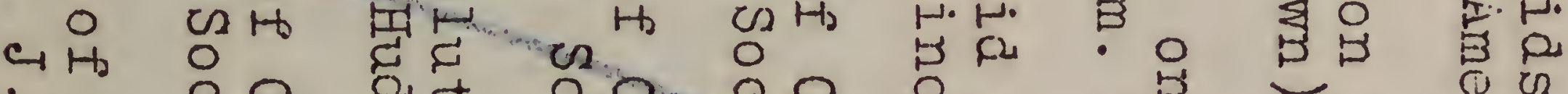

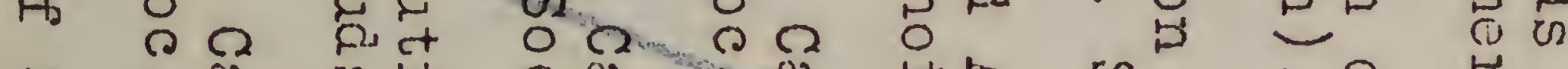

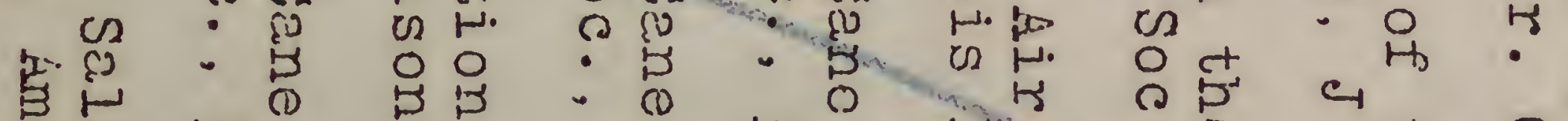

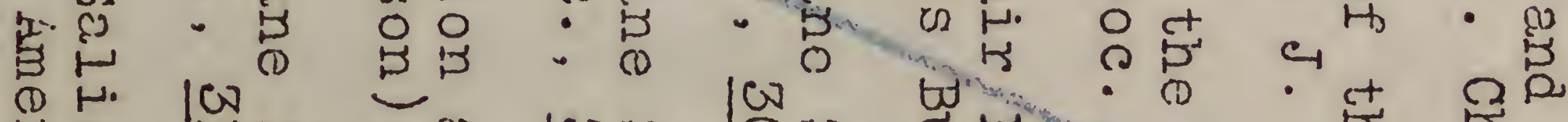
月

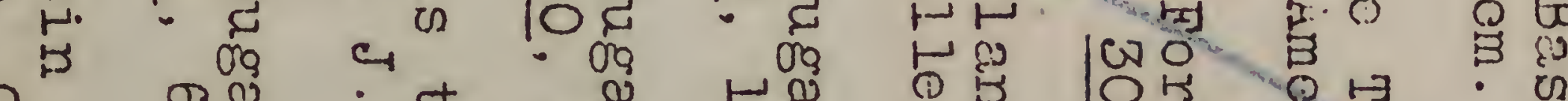

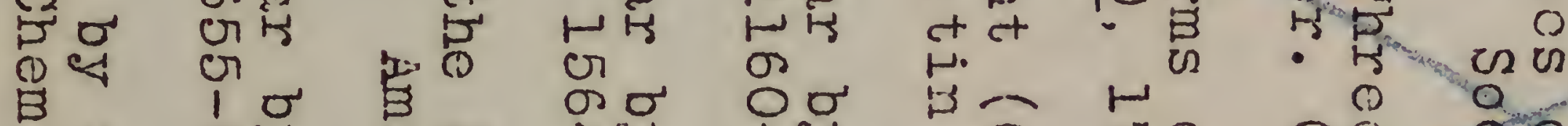
B 点 $A$ मी व

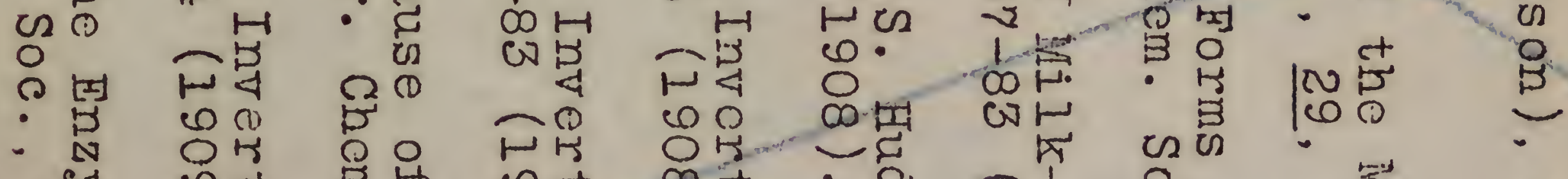

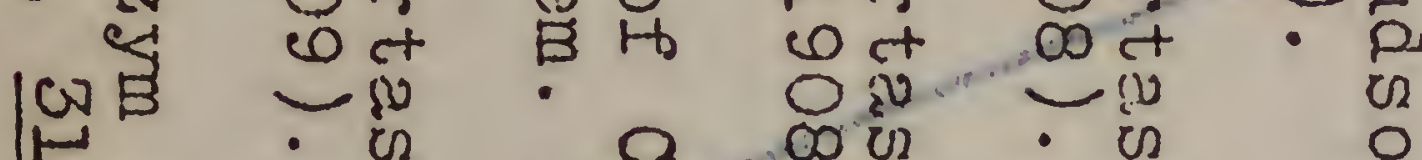

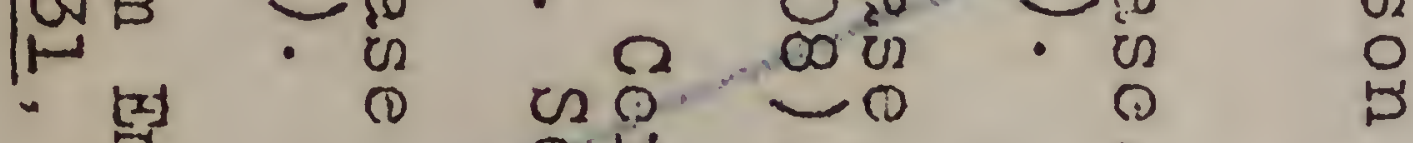

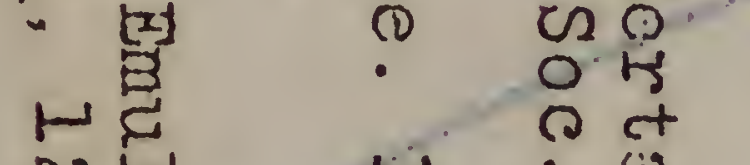

or

A es

点 $\infty$

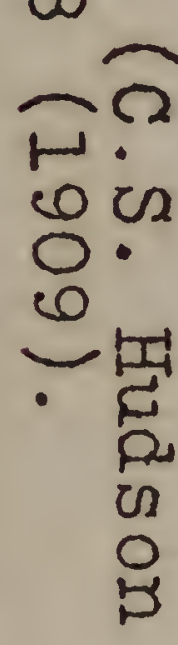
惡 H! 窃 !-1

$\log ^{0,5}$ H

管 $\widehat{P} \stackrel{1}{0}$ US 西 0 Co: H $\infty$

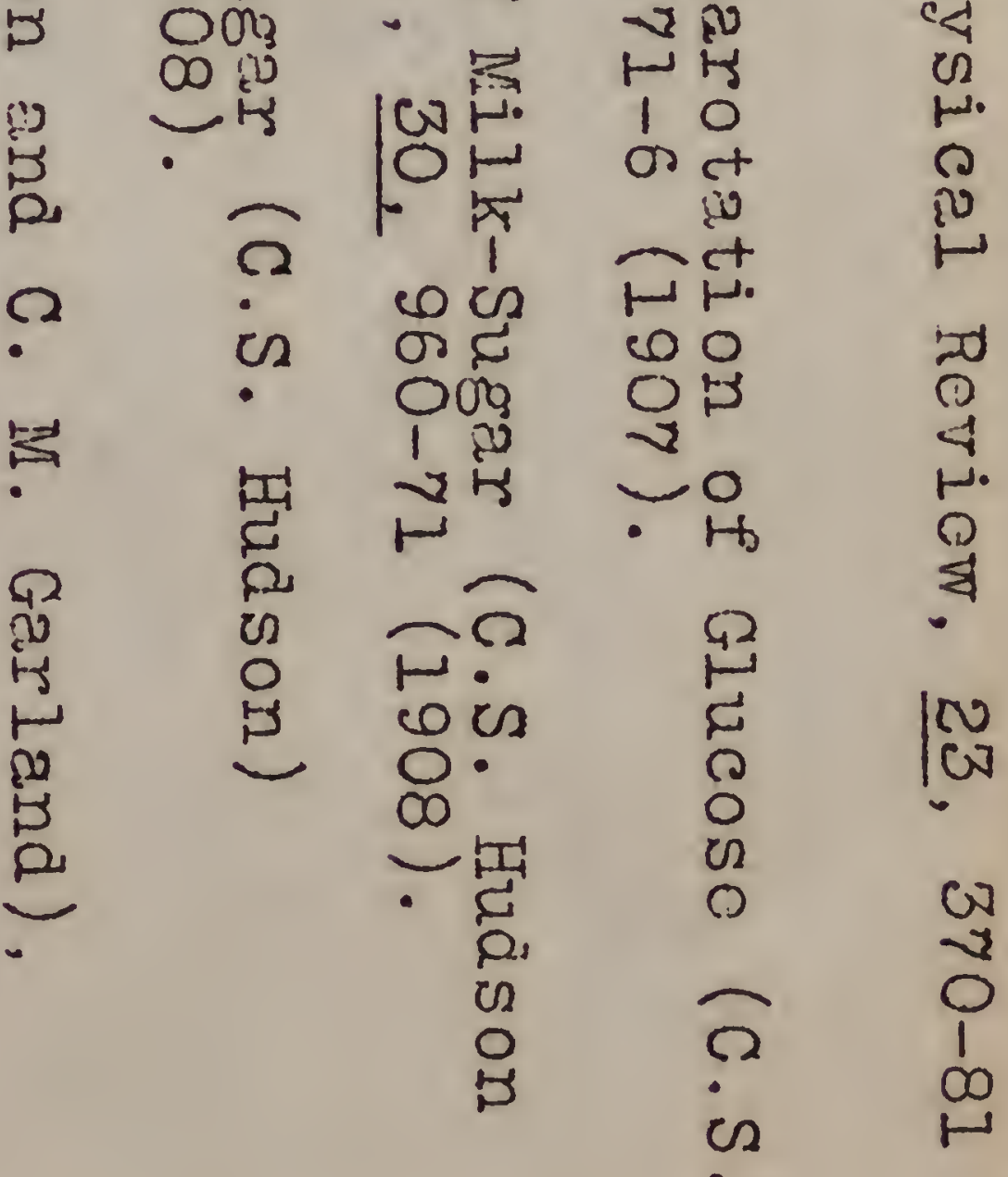


sefo.

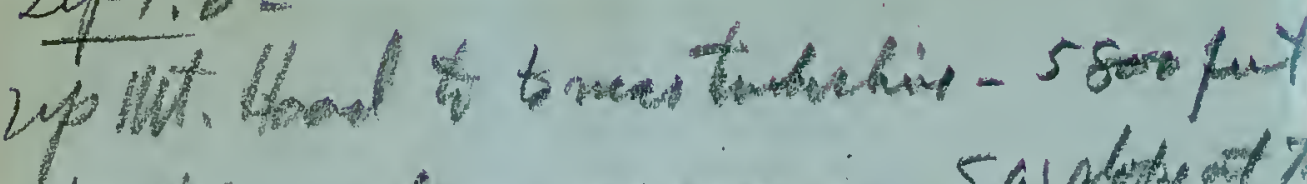

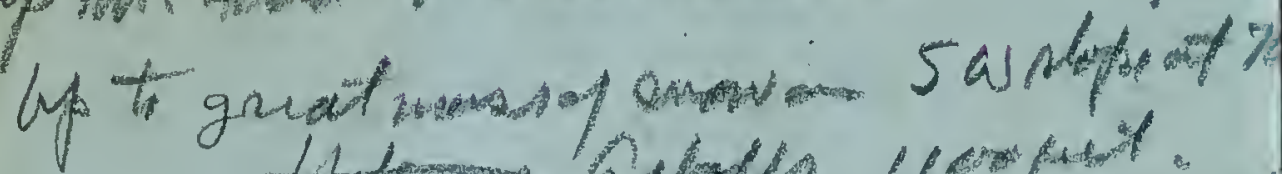
spet 19

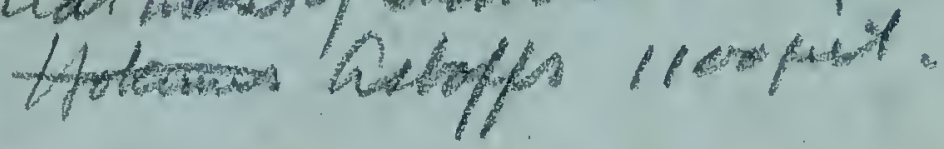

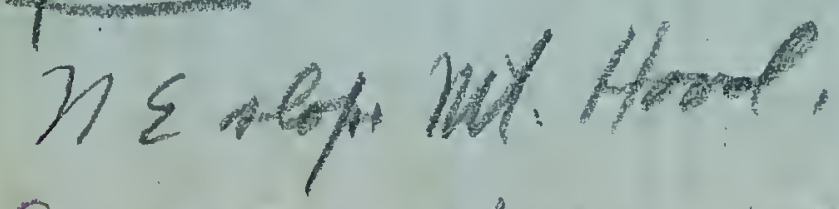

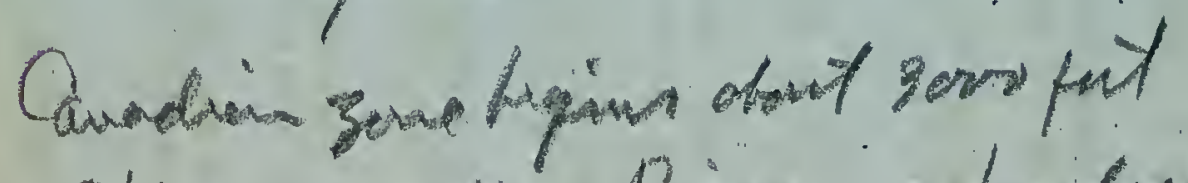
Whis quandis, pien, 2 hombeles,

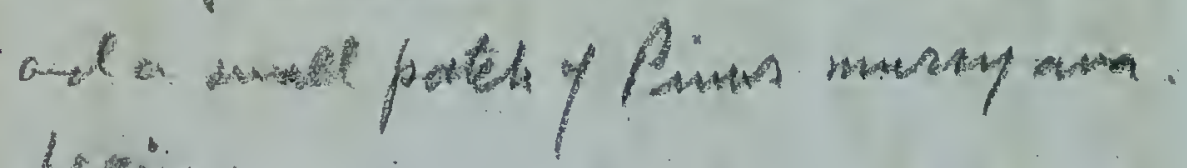
Legar.

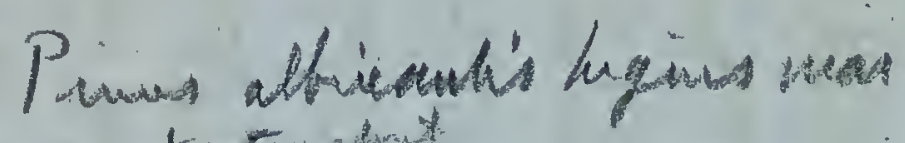
Col gavas a part

Tun tonnal of OPIII I 894. 


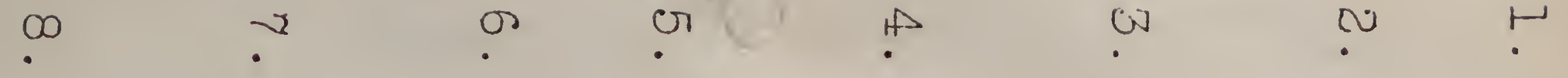

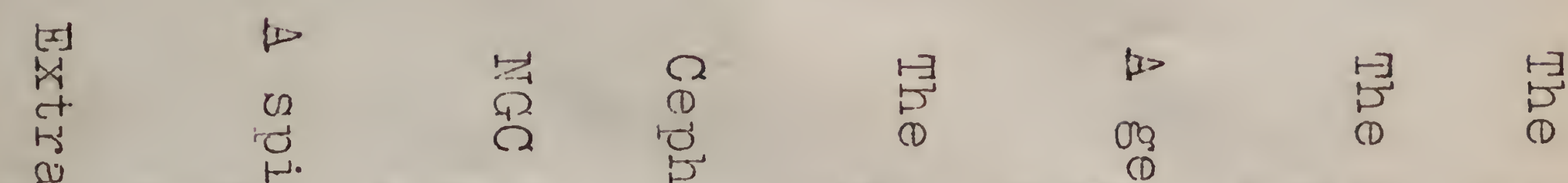

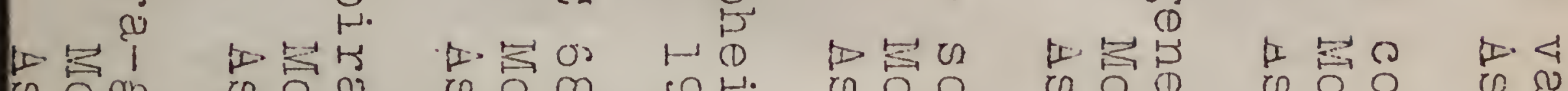

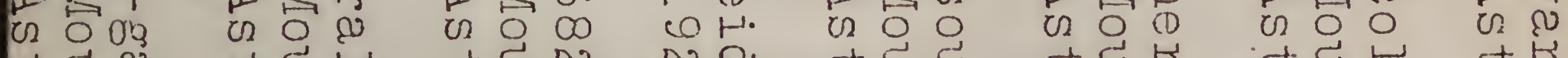

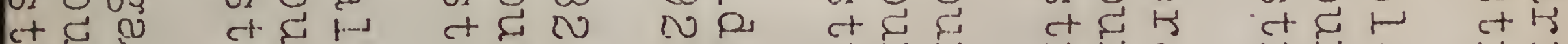

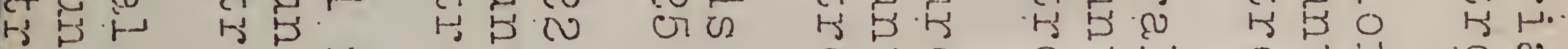

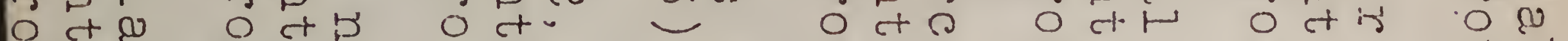

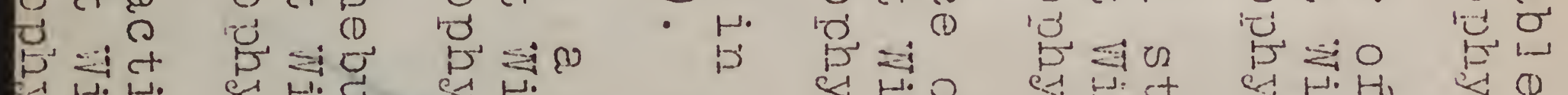

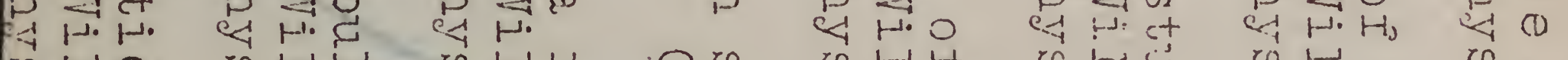

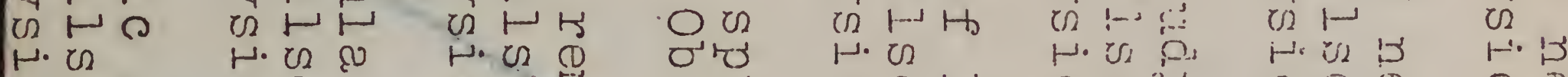

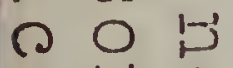

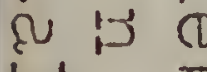

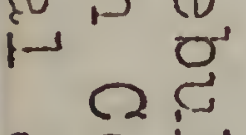
CO $0 \begin{array}{ccc}0 \\ 0\end{array}$ ctis ry. Sh h.

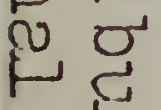
ct. 40 0,5

$\mapsto U$

Ois 2 is 0

$\mapsto \circlearrowright$

eo 10

in in

ar

\begin{tabular}{|c|c|c|}
\hline & & 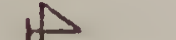 \\
\hline 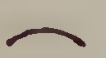 & ᄀ w. & $\mathrm{G}-$ \\
\hline co & $A C D$ & $\cos$ \\
\hline r & $=\quad 6 ! 3$ & $\therefore \quad \pi$ \\
\hline נjo & मूO & $w r$ \\
\hline - & 0. & e. \\
\hline - & $\mathrm{N}$ & iv \\
\hline & os & תו \\
\hline & 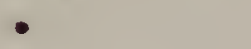 & \\
\hline
\end{tabular}

c 0 a 20

(U)

$\Omega^{2}$

c. $\mathrm{O}^{2} \mathrm{~N}$

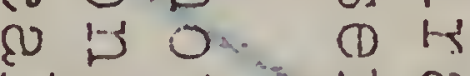

थ H. O 0 H

○ 0 W 003

0 少

inj

म. त

Q

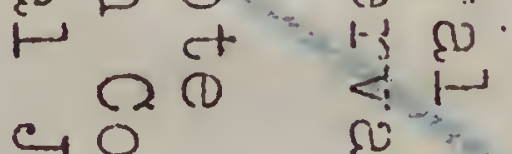

$\rightarrow 0$

第聂

O p $u^{\prime}$

ct ct

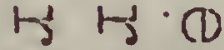

管

( $匚 \longmapsto$

ct

$\mapsto \mathrm{C}$

1.- h.

40

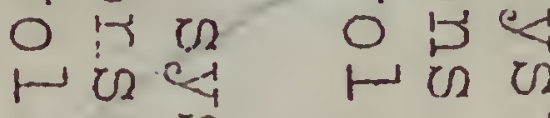

- ct trs

$\begin{array}{lll}4 & 0 \\ 0 & 0\end{array}$

0 ct U U U
-

CD

or $\ln _{-1}$

ct $A 2$

ctis

$c_{1}$

ci p

1.-i 0 吕

th 0

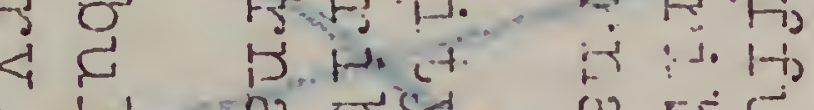

$0 ; 0$

(3) s.r.tio

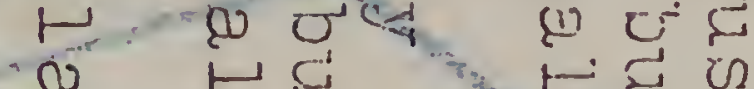

O $B$ NO

$-\infty$

No

arit if 03

क० 0 की

$1-\pi$

(1)

मㄹ 02

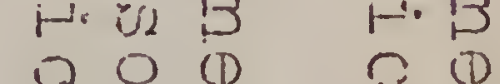

n.

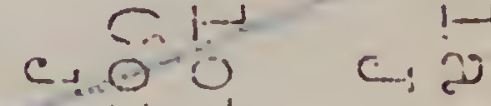

0 ij

$\because=0 \quad r=1$

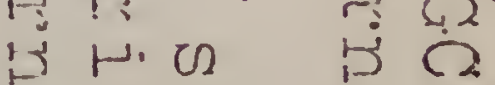

(i) Co

his id ho

$40^{-1, i} \quad 40 \Omega$

c! $1-3$

4 \& 91240

$-\quad 63$ $\mapsto v_{2}$

0 म कृ

$0 \mathrm{~B}$

$<$ L

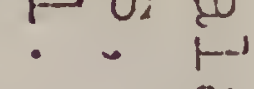

- $\Omega$

-

U

ar $0 \mathrm{ct}$

OI $\Rightarrow \mathrm{H}$

or 0 H.

or $\quad \therefore$ $\begin{array}{lll}0 & 4 \\ m & 0\end{array}$ 075. id

ठ Ni

- crip

i.

Cs

cir ro

if

年

Q..; ct

战

(U) 0 .

- 5 Cs

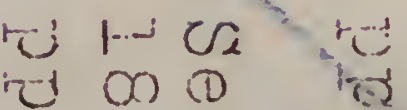

$A$ एँ

O) 20

N 010

100 .

cors

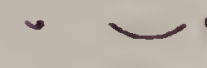

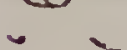

5.

$\mapsto$

- $-\frac{1}{2}$

$\stackrel{\infty}{1}-\infty$

N 10

NC ? ר

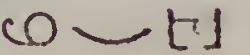

0 运

No

iv

当

8

告 